\title{
Flow Velocity, Water Temperature, and Conductivity in Shark River Slough, Everglades National Park, Florida: August 2001- June 2002
}

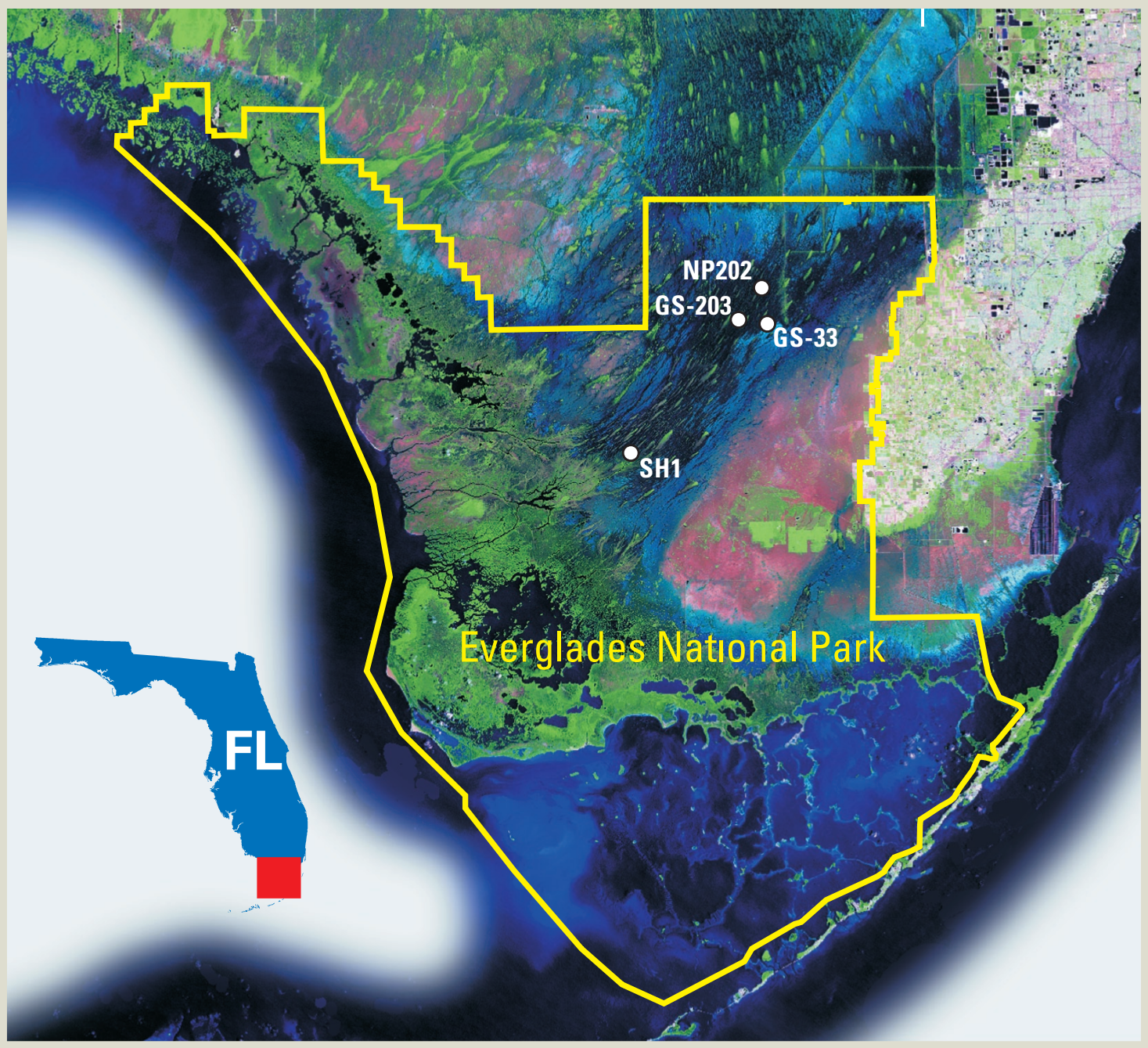

Open File Report 03-348 


\section{Flow Velocity, Water Temperature, and Conductivity in Shark River Slough, Everglades National Park, Florida: August 2001- June 2002}

By Ami L. Riscassi and Raymond W. Schaffranek

Open File Report 03-348 


\title{
U.S. Department of the Interior \\ Gale A. Norton, Secretary \\ U.S. Geological Survey Charles G. Groat, Director
}

U.S. Geological Survey, Reston, Virginia: 2003

\author{
For sale by U.S. Geological Survey, Information Services \\ Box 25286, Denver Federal Center \\ Denver, CO 80225 \\ For more information about the USGS and its products: \\ Telephone: 1-888-ASK-USGS \\ World Wide Web: http://www.usgs.gov/
}

\footnotetext{
Any use of trade, product, or firm names in this publication is for descriptive purposes only and does not imply endorsement by the U.S. Government.

Although this report is in the public domain, it contains copyrighted materials that are noted in the text. Permission to reproduce those items must be secured from the individual copyright owners.
} 


\section{Contents}

Abstract
Introduction
Description of Study Area and Monitoring Program
Purpose and Scope of Report
Acknowledgments
Selection and Description of Flow-Monitoring Sites
Methods
Measurement Techniques
Deployment Techniques and Parameter Settings
Processing Flow-Velocity, Conductivity, and Temperature Data
ADV Flow Data
TheroCAT Conductivity and Temperature Data a




\section{Figures}

1. Satellite image of south Florida showing locations of monitoring stations SH1, GS-203, GS-33, and NP202 in Everglades National Park, 1:500,000 scale ...

2. Photograph of thermistor string deployed in a dense cattail area at NP202 in Shark

River Slough, Everglades National Park, Florida.............................................................. 3

3-4. Graphs showing:

3. Conductivities measured continuously by MicroCAT probe and intermittently by hand-held YSI meter at GS-203 in Shark River Slough, Everglades National Park, Florida

4. Conductivities measured continuously by MicroCAT probe and intermittently by hand-held YSI meter at GS-33 in Shark River Slough, Everglades National Park, Florida

5-7. Plots showing:

5. Burst-averaged flow velocities, shown as vectors relative to magnetic north, at SH1 in Shark River Slough, Everglades National Park, Florida, during the 2001-2002 wet season

6. Burst-averaged flow velocities, shown as vectors relative to magnetic north, at GS-203 in Shark River Slough, Everglades National Park, Florida, during the 2001-2002 wet season.

7. Burst-averaged flow velocities, shown as vectors relative to magnetic north, at GS-33 in Shark River Slough, Everglades National Park, Florida, during the 2001-2002 wet season.

\section{Tables}

1. Site locations and instrumentation for flow-velocity and water-temperature monitoring stations, Shark River Slough, Everglades National Park, Florida

2. Deployment parameter settings for SH1, GS-203, and GS-33 ADV units, Shark River Slough, Everglades National Park, Florida

3. Deployment specifications and parameter settings for SH1, GS-203, GS-33, and NP202 thermistor strings, Shark River Slough,

Everglades National Park, Florida

4. ADV data-collection summaries for SH1, GS-203, and GS-33, Shark River Slough, Everglades National Park, Florida

5. Post-processing changes to ADV deployment parameter settings for SH1, GS-203, and GS-33, Shark River Slough, Everglades National Park, Florida 
A-1. Daily mean flow velocities and water depths at station SH1 during deployment period 08/15/01 1500 - 10/10/01 1300...... 14

A - 2. Daily mean flow velocities and water depths at station $\mathrm{SH} 1$ during deployment period 10/11/01 1130 - 11/06/01 1230.....

A-3. Daily mean flow velocities and water depths at station $\mathrm{SH} 1$ during deployment period 11/08/01 1000-01/23/02 1500

A - 4. Daily mean flow velocities and water depths at station SH1 during deployment period 01/24/02 1500 - 02/12/02 1230

B - 1. Daily mean flow velocities, MicroCAT water temperatures and specific conductances, and water depths at station GS-203 during deployment period 08/09/01 1330 - 08/15/01 1530

B - 2. Daily mean flow velocities, MicroCAT water temperatures and specific conductances, and water depths at station GS-203

during deployment period 08/16/01 1100 - 10/10/01 1400

B - 3. Daily mean flow velocities, MicroCAT water temperatures and specific conductances, and water depths at station GS-203

during deployment period 10/11/02 1030 - 11/06/01 1130

B - 4. Daily mean flow velocities, MicroCAT water temperatures and specific conductances, and water depths at station GS-203 during deployment period 11/08/01 0900 - 01/23/02 1600

B - 5. Daily mean flow velocities, MicroCAT water temperatures and specific conductances, and water depths at station GS-203 during deployment period 01/24/02 1505-02/12/02 1335

C - 1. Daily mean flow velocities, MicroCAT water temperatures and specific conductances, and water depths at station GS-33 during deployment period 08/09/01 1600 - 08/15/01 1530

C - 2. Daily mean flow velocities, MicroCAT water temperatures and specific conductances, and water depths at station GS-33 during deployment period 08/16/01 1000 - 10/10/01 1530

C - 3. Daily mean flow velocities, MicroCAT water temperatures and specific conductances, and water depths at station GS-33 during deployment period 10/11/01 0900 - 11/06/01 1000

C - 4. Daily mean flow velocities, MicroCAT water temperatures and specific conductances, and water depths at station GS-33 during deployment period 11/08/01 0900-01/23/02 1630

C - 5. Daily mean flow velocities, MicroCAT water temperatures and specific conductances, and water depths at station GS-33 during deployment period 01/25/02 0915 - 02/12/02 1445. 


\section{Conversion Factors, Abbreviations, and Horizontal Datum}

\begin{tabular}{lll}
\hline Divide & By & To obtain \\
\hline & Length & \\
\hline millimeter $(\mathrm{mm})$ & 25.4 & inch (in) \\
centimeter $(\mathrm{cm})$ & 2.54 & inch (in) \\
meter $(\mathrm{m})$ & 0.3048 & foot (ft) \\
kilometer $(\mathrm{km})$ & 1.609 & mile $(\mathrm{mi})$ \\
\hline & Velocity & \\
\hline centimeter per second $(\mathrm{cm} / \mathrm{s})$ & 30.48 & foot per second $(\mathrm{ft} / \mathrm{s})$
\end{tabular}

Temperature in degrees Celsius $\left({ }^{\circ} \mathrm{C}\right)$ may be converted to degrees Fahrenheit $\left({ }^{\circ} \mathrm{F}\right)$ as follows:

$$
{ }^{\circ} \mathrm{F}=\left(1.8 x^{\circ} \mathrm{C}\right)+32
$$

Direction of flow is reported in degrees clockwise from magnetic north ( ${ }^{\circ} \mathrm{CW}$ from MN).

Frequency of velocity measurements is reported in hertz $(\mathrm{Hz})$.

Salinity is reported in parts per thousand (ppt).

Signal-to-Noise ratio is reported in decibels (dB).

Specific conductance is reported in microsiemens per centimeter $(\mu \mathrm{S} / \mathrm{cm})$.

Horizontal coordinates are referenced to North American Datum of 1983 (NAD83). 


\title{
Flow Velocity, Water Temperature, and Conductivity in Shark River Slough, Everglades National Park, Florida: August 2001- June 2002
}

\author{
Ami L. Riscassi and Raymond W. Schaffranek
}

\begin{abstract}
The data-collection effort described in this report is in support of the U.S. Geological Survey (USGS) Place-Based Studies project investigating "Forcing Effects on Flow Structure in Vegetated Wetlands of the Everglades." Data collected at four locations in Shark River Slough, Everglades National Park, during the 2001-2002 wet season are documented in the report and methods used to process the data are described. Daily mean flow velocities, water temperatures, and specific conductance values are presented in the appendices of the report. The quality-checked and edited data have been compiled and stored on the USGS South Florida Information Access (SOFIA) website http://sofia.usgs.gov.
\end{abstract}

\section{Introduction}

A major thrust of the Everglades restoration effort, according to the Comprehensive Everglades Restoration Plan available on the website $h t t p: / / w w w . e v e r g l a d e s p l a n . o r g$, is to restore the natural functioning of the ecosystem to pre-drainage conditions. This objective requires detailed knowledge of the hydrologic and hydraulic factors that affect the natural flow of water through the Everglades wetlands. The heterogeneous vegetation, small topographic gradient, microtopography, and ridge-and-slough structure of the landscape variously affect flows through the vast mosaic of sloughs, marshes, and wet prairies that make up the Everglades. The data collected in this project document the temporal and spatial variability of the extremely low velocity of shallow water in the heterogeneous wetlands and provide insight into the hydrologic and hydraulic processes that affect its flow through the low-gradient landscape.

Shark River Slough is the dominant path of surface-water flow in Everglades National Park (ENP) (fig. 1). It conveys freshwater inflows discharged through culverts and hydraulic control structures along Tamiami Trail to the coastal mangrove ecotone of the southwest Gulf Coast of Florida. Flow-velocity, water-temperature, and conductivity data collected in Shark

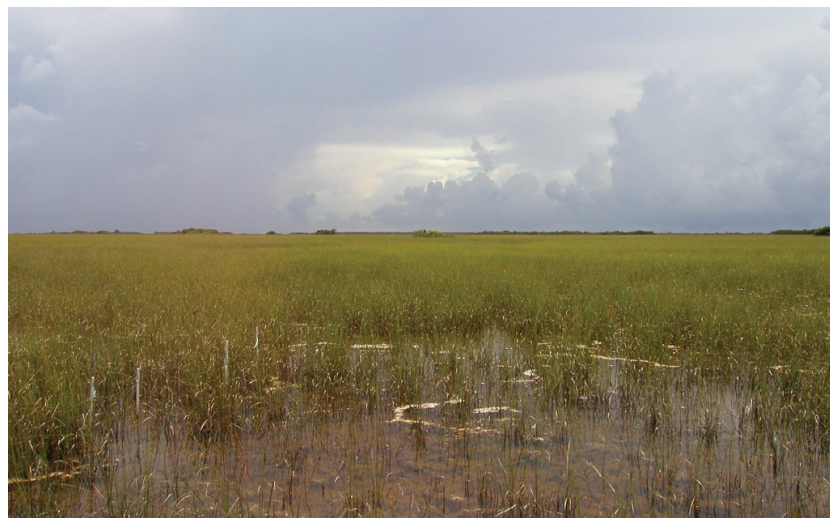

Photograph courtesy D. Briane Adams, retired USGS.

River Slough during August 2001 through June 2002 (20012002 wet season) are presented in this report. These data supplement the data collected during the 1999-2000 and 2000-2001 wet seasons documented by Riscassi and Schaffranek (2002).

\section{Description of Study Area and Monitoring Program}

The freshwater wetlands of Shark River Slough are a mixture of tree islands, sawgrass marshes, wet prairies, and sloughs that variously affect the conveyance of water to the coastal mangrove ecotone. Flow velocities and (or) related hydrologic parameters were monitored at four sites (SH1, GS-203, GS33, and NP202) in Shark River Slough with differing vegetative characteristics (fig. 1). At all four sites, temperatures were monitored in the plant litter, throughout the water column, on the water surface, and in the air above the water column using thermistors (thermally sensitive resistors). At three of the sites (SH1, GS-203, and GS-33), flow velocities were monitored bi-hourly at a fixed point in the water column using acoustic Doppler velocity (ADV) meters. At two of the three ADV monitoring sites (GS-203 and GS-33), conductivities and water temperatures were monitored bi-hourly at a fixed point in the water column using water-quality probes. 


\section{Purpose and Scope of Report}

The data collected in the 2001-2002 wet season, as processed and presented in this report, are intended to supplement the data documented in Riscassi and Schaffranek (2002) for the 1999-2001 wet seasons. This report identifies the deployment specifications, describes the data-processing techniques, and presents the flow-velocity and related hydrologic data collected at four monitoring sites. Daily mean flow speeds and directions, specific conductance values, and water temperatures are listed in the report appendices. Quality-checked and edited data are available for downloading from the Data Exchange page of the USGS South Florida Information Access (SOFIA) website http://sofia.usgs.gov.

\section{Acknowledgments}

Gordon Anderson, USGS, provided ancillary stage data from the SH1 hydrologic monitoring station. Kevin Kotun, National Park Service (NPS)/ENP, provided ancillary stage data from the NP203 and P33 hydrologic monitoring stations. Edward German and Sandra Kinnaman, both of USGS, provided meteorological data from the P33 and SH1 evapotranspiration stations for flow analyses. Edward Simonds, USGS, provided logistical and technical support. Michael Duff, formerly of the USGS, developed the ADV filtering and plotting programs used to process, analyze, and display the flow-velocity data.

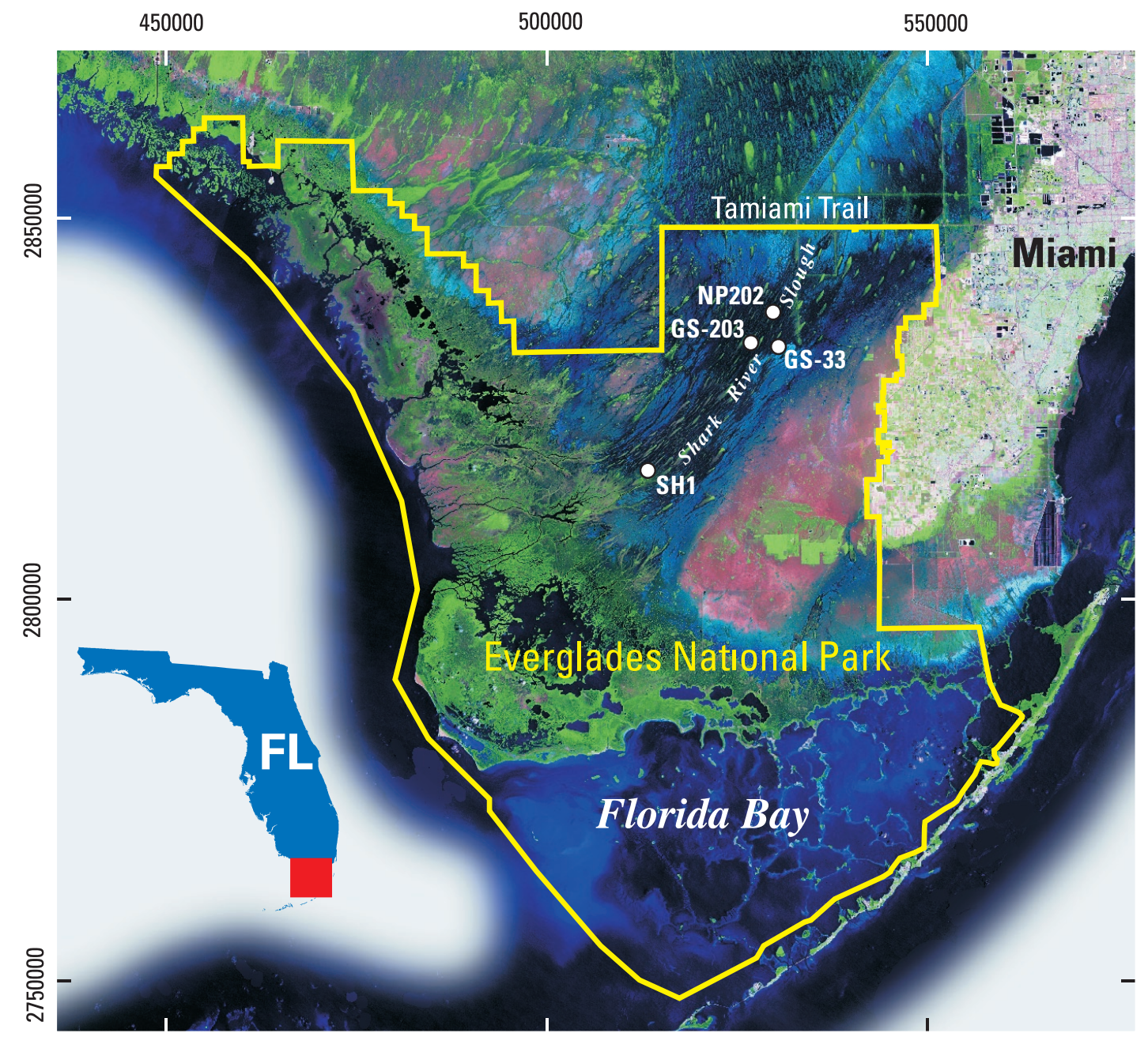

Base from U.S. Geological Survey South Florida satellite image map, 1993 UniversalTransverse Metcator, NAD 83, Zone 17 Meters

Figure 1. Satellite image of south Florida showing locations of monitoring stations SH1, GS-203, GS-33, and NP202 in Everglades National Park, 1:500,000 scale. 


\section{Selection and Description of Flow- Monitoring Sites}

Locations of the flow-velocity and water-temperature monitoring stations SH1, GS-203, GS-33, and NP202 are shown in figure 1. Thermistor strings were deployed at all four sites. ADV units were deployed at SH1, GS-203, and GS-33. The ADV units at GS-203 and GS-33 were equipped with integrated MicroCAT conductivity/temperature probes.

Sites SH1, GS-203, and GS-33 were established in differing vegetative communities as previously described in Riscassi and Schaffranek (2002). The ADV unit installed at GS-33 in August 2001 was intended to provide flow-velocity data to supplement water and air temperature profiling initiated at the site during the 2000-2001 wet season (Riscassi and Schaffranek, 2002). In August 2001, a thermistor string was deployed at the ENP NP202 hydrologic station (fig. 2) to monitor the temperature profile in an area of dense cattails. Site locations and instrumentation deployed at the sites during the 2001-2002 wet season are identified in table 1 for all four monitoring stations.

\section{Methods}

Methods developed to measure the flow velocity, temperature, and conductivity are identical to those defined in Riscassi and Schaffranek (2002). A brief description of the measurement techniques and a summary of the deployment techniques and critical parameter settings for the instrumentation are provided in this section of the report.

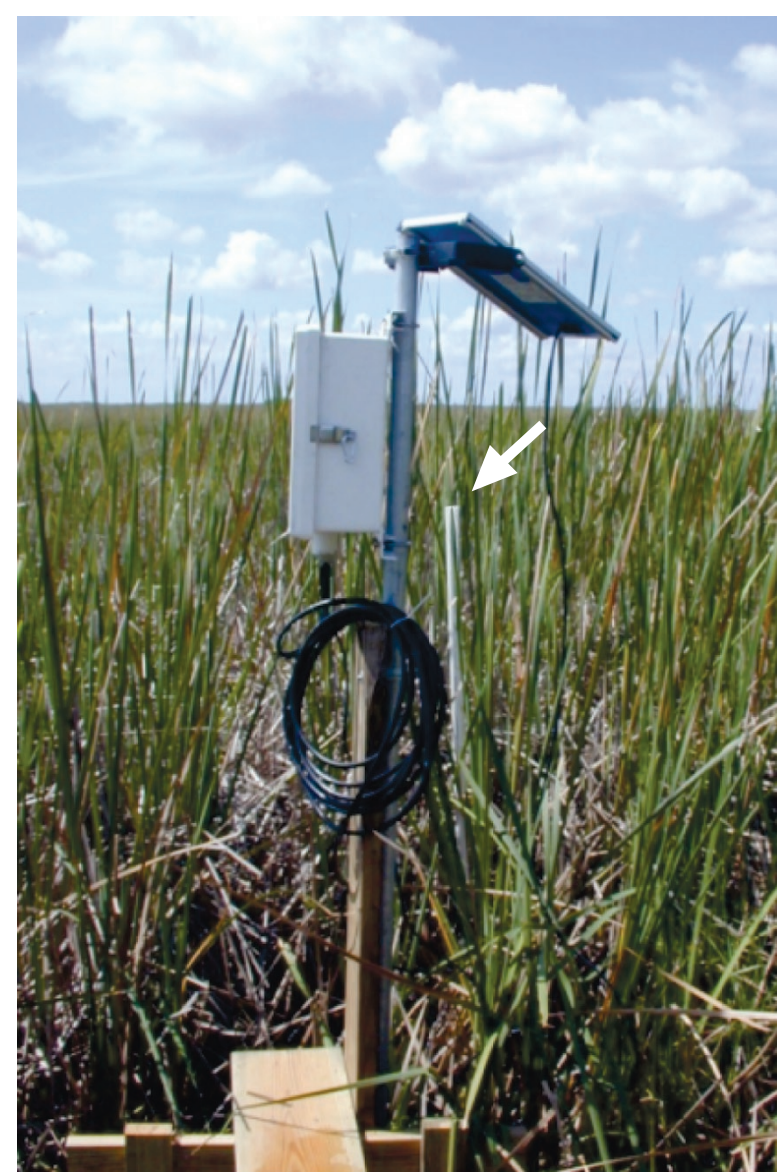

Figure 2. Thermistor string (attached to PVC pipe in center background indicated by arrow) deployed in a dense cattail area at NP202 in Shark River Slough, Everglades National Park, Florida.

Table 1. Site locations and instrumentation for flow-velocity and water-temperature monitoring stations, Shark River Slough, Everglades National Park, Florida

[UTM, Universal Transverse Mercator; NAD, North American Datum; m, meter; ADV, Acoustic Doppler Velocity]

\begin{tabular}{|c|c|c|c|c|}
\hline \multirow{2}{*}{$\begin{array}{l}\text { Site } \\
\text { Name }\end{array}$} & \multicolumn{2}{|c|}{$\begin{array}{l}\text { UTM Coordinates } \\
\text { NAD 83, Zone } 17\end{array}$} & \multirow[t]{2}{*}{ Location } & \multirow[t]{2}{*}{ Instrumentation } \\
\hline & East (m) & North (m) & & \\
\hline GS-203 & 526133 & 2833920 & $\begin{array}{l}160 \mathrm{~m} \text { from NP203 hydrologic station } \\
\text { at } 22.7 \text { degrees west of south }\end{array}$ & $\begin{array}{l}\text { ADV unit, MicroCAT meter, thermistor } \\
\text { string, data logger, solar panel }\end{array}$ \\
\hline GS-33 & 529637 & 2833457 & $\begin{array}{l}440 \mathrm{~m} \text { from P33 hydrologic station at } \\
30.6 \text { degrees west of north }\end{array}$ & $\begin{array}{l}\text { ADV unit, MicroCAT meter, thermistor } \\
\text { string, data logger, solar panel }\end{array}$ \\
\hline SH1 & 515249 & 2817258 & $\begin{array}{l}10 \text { m southwest of SH1 hydrologic } \\
\text { station }\end{array}$ & $\begin{array}{l}\text { ADV unit, thermistor string, data logger, } \\
\text { solar panel }\end{array}$ \\
\hline NP202 & 529245 & 2838450 & $\begin{array}{l}\text { Co-located with NP202 hydrologic } \\
\text { station }\end{array}$ & Thermistor string, data logger, solar panel \\
\hline
\end{tabular}




\section{Measurement Techniques}

Flow velocities were measured at a fixed point in the water column using SonTek/YSI $10 \mathrm{MHz}$ ADVField units (Sontek, 2001). Conductivity and temperature data were measured near the top of the litter layer using MicroCAT model SBE 37-SI meters developed by Sea-Bird Electronics (SeaBird Electronics, 1999). Temperatures were measured at 5-, $15-$, or 30-minute intervals in the plant litter, at 5- or $10-\mathrm{cm}-$ depth increments throughout the water column, on the water surface, and in the air above the water column using glassencapsulated thermistors manufactured by Yellow Springs Instruments (YSI) (Yellow Springs Instruments, 1998). Riscassi and Schaffranek (2002) present detailed descriptions of the instrumentation, including accuracy and resolution specifications.

\section{Deployment Techniques and Parameter Settings}

Deployment techniques and procedures used for the 2001-2002 wet season were the same as those documented in Riscassi and Schaffranek (2002) for the 1999-2001 wet seasons. ADV-deployment parameter settings at SH1, GS203, and GS-33 are provided in table 2. MicroCAT meters were deployed 6 and $13 \mathrm{~cm}$ above the plant-litter layer near the ADV meters at GS-33 and GS-203, respectively. Thermistor positions, in relation to the top of the plant-litter layer, and temperature recording intervals at all four monitoring sites are listed in table 3 . The ADV recording interval and sample volume location, relative to the top of the plant-litter layer, are provided in table 4 for each ADV deployment. Approximate water depths determined from water levels recorded at nearby hydrologic stations also are listed in table 4.

Table 2. Deployment parameter settings for SH1, GS-203, and GS-33 ADV units, Shark River Slough, Everglades National Park, Florida

[min, minute; Temp, temperature; ${ }^{\circ} \mathrm{C}$, degrees Celsius; ppt, parts per thousand; Vel, velocity; $\mathrm{cm} / \mathrm{s}$, centimeter per second; Coord, Coordinate; EDT, Eastern Daylight Time; EST, Eastern Standard Time; ENU, geodetic East North Up; XYZ, Cartesian coordinates].

\begin{tabular}{|c|c|c|c|c|c|}
\hline \multicolumn{6}{|c|}{ Deployment Parameters } \\
\hline Deployment period ${ }^{1}$ & $\begin{array}{c}\text { Recording } \\
\text { interval } \\
\text { (min) }\end{array}$ & $\begin{array}{l}\text { Temp } \\
\left({ }^{\circ} \mathrm{C}\right)\end{array}$ & $\begin{array}{c}\text { Salinity } \\
\text { (ppt) }\end{array}$ & $\begin{array}{l}\text { Vel range } \\
(\mathrm{cm} / \mathrm{s})\end{array}$ & $\begin{array}{l}\text { Coord } \\
\text { system }\end{array}$ \\
\hline \multicolumn{6}{|c|}{$\begin{array}{c}\text { SH1 } \\
\text { 2001-2002 wet season }\end{array}$} \\
\hline 08/15/01 $1500-10 / 10 / 011300$ EDT & 30 & 25 & 0.0 & $+/-250$ & ENU \\
\hline 10/11/01 $1130-11 / 06 / 011230$ EDT & 30 & 25 & 0.0 & $+/-10$ & ENU \\
\hline 11/08/01 $1000-01 / 23 / 021500$ EST & 30 & 25 & 0.0 & $+/-10$ & ENU \\
\hline 01/24/02 $1500-02 / 12 / 021230$ EST & 30 & 25 & 0.0 & $+/-10$ & ENU \\
\hline \multicolumn{6}{|c|}{$\begin{array}{c}\text { GS-203 } \\
\text { 2001-2002 wet season }\end{array}$} \\
\hline 08/09/01 $1330-08 / 15 / 011530$ EDT & 30 & 25 & 0.0 & $+/-10$ & $\mathrm{XYZ}$ \\
\hline 08/16/01 $1100-10 / 10 / 011400$ EDT & 30 & 25 & 0.0 & $+/-10$ & XYZ \\
\hline 10/11/02 1030 - 11/06/01 1130 EDT & 30 & 25 & 0.0 & $+/-10$ & $\mathrm{XYZ}$ \\
\hline 11/08/01 $0900-01 / 23 / 021600$ EST & 30 & 25 & 0.0 & $+/-10$ & ENU \\
\hline 01/24/02 1505-02/12/02 1335² EST & 30 & 25 & 0.0 & $+/-10$ & ENU \\
\hline \multicolumn{6}{|c|}{$\begin{array}{c}\text { GS-33 } \\
\text { 2001-2002 wet season }\end{array}$} \\
\hline 08/09/01 $1600-08 / 15 / 011530$ EDT & 30 & 30 & 0.0 & $+/-250$ & XYZ \\
\hline 08/16/01 $1000-10 / 10 / 011530$ EDT & 30 & 30 & 0.0 & $+/-250$ & $\mathrm{XYZ}$ \\
\hline 10/11/01 $1600-11 / 06 / 011000$ EDT & 30 & 25 & 0.0 & $+/-10$ & ENU \\
\hline 11/08/01 $0900-01 / 23 / 021630$ EST & 30 & 25 & 0.0 & $+/-10$ & ENU \\
\hline 01/25/02 0915 - 02/12/02 1445² EST & 30 & 25 & 0.0 & $+/-10$ & ENU \\
\hline
\end{tabular}

${ }^{1}$ Excludes any invalid data segments at beginning and end of deployment record.

${ }^{2}$ Data collection inadvertently initiated at non-multiple time interval. 
Table 3. Deployment specifications and parameter settings for SH1, GS-203, GS-33, and NP202 thermistor strings, Shark River Slough, Everglades National Park, Florida

[min, minute; cm, centimeter; EDT, Eastern Daylight Time; EST, Eastern Standard Time]

\begin{tabular}{|c|c|c|}
\hline Deployment Period & $\begin{array}{l}\text { Recording interval } \\
\text { (min) }\end{array}$ & $\begin{array}{l}\text { Thermistor height }{ }^{1} \\
\text { (cm) }\end{array}$ \\
\hline & $\begin{array}{c}\text { SH1 } \\
\text { 2001-2002 wet season }\end{array}$ & \\
\hline 08/15/01 $1350-10 / 11 / 011050$ EDT & 5 & $0,10,20,30,40,50,60,70,80,90,110$ \\
\hline 10/11/01 1055-11/06/01 1245 EST & 5 & $0,10,20,30,40,50,60,70,80,90,110$ \\
\hline 11/06/01 1250-01/23/02 1155 EST & 5 & $0,10,20,30,40,50,60,70,80,90,110$ \\
\hline 01/23/02 1200-02/12/02 $1230 \mathrm{EST}$ & 5 & $0,10,20,30,40,50,60,70,80,90,110$ \\
\hline \multirow[t]{2}{*}{ 02/12/02 $1245-07 / 25 / 020830^{2}$ EST } & 15 & $0,10,20,30,40,50,60,70,80,90,110$ \\
\hline & $\begin{array}{c}\text { GS-203 } \\
\text { 2001-2002 wet season }\end{array}$ & \\
\hline 08/08/01 $1800-10 / 11 / 010930$ EDT & 30 & $0,10,20,25,30,35,40,45,55,65$, water surface \\
\hline 10/26/01 1810-11/06/01 1155 EST & 5 & $0,10,20,25,30,35,40,45,55,65$, water surface \\
\hline 11/06/01 $1200-01 / 23 / 021540$ EST & 5 & $0,10,20,25,30,35,40,45,55,65$, water surface \\
\hline 01/23/02 1545-02/12/02 1410 EST & 5 & $0,10,20,25,30,35,40,45,55,65$, water surface \\
\hline \multirow[t]{2}{*}{ 02/12/02 $1415-06 / 27 / 020845^{3}$ EST } & 15 & $0,10,20,25,30,35,40,45,55,65$, water surface \\
\hline & $\begin{array}{c}\text { GS-33 } \\
\text { 2001-2002 wet season }\end{array}$ & \\
\hline 08/08/01 $1630-10 / 11 / 010830$ EDT & 30 & $0,10,20,25,30,35,40,45,55,65$, water surface ${ }^{6}$ \\
\hline 10/11/01 0910 - 11/06/01 1030 EST & 5 & $0,10,20,25,30,35,40,45,55,65$, water surface ${ }^{6}$ \\
\hline 11/06/01 1035-01/06/02 0210 EST & 5 & $0,10,20,25,30,35,40,45,55,65$, water surface ${ }^{6}$ \\
\hline 01/23/02 1705-02/12/02 1515 EST & 5 & $0,10,20,25,30,35,40,45,55,65$, water surface ${ }^{6}$ \\
\hline \multirow[t]{2}{*}{ 02/12/02 $1530-06 / 27 / 021115^{4}$ EST } & 15 & $0,10,20,25,30,35,40,45,55,65$, water surface ${ }^{6}$ \\
\hline & $\begin{array}{c}\text { NP202 } \\
\text { 2001-2002 wet season }\end{array}$ & \\
\hline 08/10/01 $1130-10 / 10 / 011440$ EDT & 5 & $0,10,20^{7}, 30,40,50,60,70,80,90$, water surface \\
\hline 10/10/01 $1445-11 / 06 / 011105$ EDT & 5 & $0,10,20^{8}, 30,40,50,60,70,80,90$, water surface \\
\hline 11/06/01 1110-01/24/02 1620 EST & 5 & $0,10,20,30,40,50,60,70,80,90$, water surface \\
\hline 01/24/02 1625-02/13/02 0835 EST & 5 & $0,10,20,30,40,50,60,70,80,90$, water surface \\
\hline 02/13/02 $0840-06 / 27 / 021245^{5}$ EST & 15 & $0,10,20,30,40,50,60,70,80,90$, water surface \\
\hline
\end{tabular}

${ }^{1}$ Measured from 1-2 cm below top of plant-litter layer.

${ }^{2}$ All thermistors out of water from approximately 04/04/02 - 06/02/02.

${ }^{3}$ All thermistors out of water from approximately 03/18/02 - 06/02/02.

${ }^{4}$ All thermistors out of water from approximately 03/18/02 - 06/02/02.

${ }^{5}$ All thermistors out of water from approximately 03/24/02 - 06/01/02.

${ }^{6}$ Floating water-surface thermistor hung on vegetation, therefore not measuring water temperature.

${ }^{7}$ No data recorded for thermistor 9/7/01 0835 - 10/10/01 1440 due to communications failure.

${ }^{8}$ No data recorded for thermistor 10/10/01 1130 - 10/29/01 0310 due to communications failure. 
Table 4. ADV data-collection summaries for SH1, GS-203, and GS-33, Shark River Slough, Everglades National Park, Florida

[min, minute; cm, centimeter; avg, average; EDT, Eastern Daylight Time; EST, Eastern Standard Time]

\begin{tabular}{|c|c|c|c|}
\hline Deployment period ${ }^{1}$ & $\begin{array}{l}\text { Recording } \\
\text { interval } \\
\text { (min) }\end{array}$ & $\begin{array}{l}\text { Sample volume location } \\
\text { above top of litter } \\
\text { (cm) }\end{array}$ & $\begin{array}{l}\text { Approximate water } \\
\text { depth range (avg) } \\
\text { (cm) }\end{array}$ \\
\hline \multicolumn{4}{|c|}{$\begin{array}{c}\text { SH1 } \\
\text { 2001-2002 wet season }\end{array}$} \\
\hline 08/15/01 $1500-10 / 10 / 011300$ EDT & 30 & 22 & $37-68(50)$ \\
\hline 10/11/01 1130 - 11/06/01 1230 EDT & 30 & 22 & $56-65(61)$ \\
\hline 11/08/01 $1000-01 / 23 / 021500$ EST & 30 & 22 & $41-59(50)$ \\
\hline 01/24/02 $1500-02 / 12 / 021230$ EST & 30 & 22 & $31-40(35)$ \\
\hline
\end{tabular}

GS-203

2001-2002 wet season

\begin{tabular}{llll}
\hline $08 / 09 / 01 ~ 1330-08 / 15 / 01 ~ 1530$ EDT & 30 & 15 & $27-29(28)$ \\
$08 / 16 / 011100-10 / 10 / 011400$ EDT & 30 & 27 & $27-56(39)$ \\
$10 / 11 / 021030-11 / 06 / 011130$ EDT & 30 & 27 & $50-61(55)$ \\
$11 / 08 / 010900-01 / 23 / 021600$ EST & 30 & 27 & $26-56(46)$ \\
$01 / 24 / 021505-02 / 12 / 021335^{2}$ EST & 30 & 10 & $19-25(22)$ \\
\hline
\end{tabular}

GS-33

2001-2002 wet season

\begin{tabular}{llll}
\hline $08 / 09 / 011600-08 / 15 / 011530$ EDT & 30 & 10 & $30-31(30)$ \\
$08 / 16 / 011000-10 / 10 / 011530$ EDT & 30 & 10 & $31-60(42)$ \\
$10 / 11 / 011600-11 / 06 / 011000$ EDT & 30 & 26 & $50-61(54)$ \\
$11 / 08 / 010900-01 / 23 / 021630$ EST & 30 & 26 & $30-56(46)$ \\
$01 / 25 / 020915-02 / 12 / 021445^{2}$ EST & 30 & 13 & $24-29(26)$ \\
\hline
\end{tabular}

${ }^{1}$ Excludes any invalid data segments at beginning and end of deployment record.

${ }^{2}$ Data collection inadvertently initiated at non-multiple time interval.

\section{Processing Flow-Velocity, Conduc- tivity, and Temperature Data}

In post-processing the flow-velocity, conductivity, and temperature data, factors such as instrument accuracies and environmental difficulties associated with the wetland deployments were considered in the development of applicable processing techniques. The techniques and editing criteria used to quality check and verify the data are summarized in the following report sections.

\section{ADV Flow Data}

The techniques used to process ADV data collected during the 2001-2002 wet season are a continuation of methods developed and documented previously in Riscassi and Schaffranek (2002). A preliminary data-inspection process, a pre- editing data-conversion process, a quantitative data-editing process, and a qualitative inspection process were used to edit, verify, and otherwise process the recorded flow-velocity data. Specific deployment parameter settings used to collect the data and post-processing corrections applied to edit the data are provided in table 5.

Editing and filtering criteria used to process the ADV data for the 2001-2002 wet season include those suggested by the instrument manufacturer to detect suspect data attributed to poor signal quality (SonTek, 2001) and those developed during the processing and concurrent analysis of past ADV data (Ball and Schaffranek, 2000; Riscassi and Schaffranek, 2002). The equipment manufacturer suggests minimum signal-to-noise-ratio (SNR) and statistical-correlation values of $5 \mathrm{~dB}$ and 70 percent, respectively, as indicative of good acoustic signal quality (SonTek, 2001). SNR values are derived from acoustic signal strengths measured during the deployment and the ambient electron- 
Table 5. Post-processing changes to ADV deployment parameter settings for SH1, GS-203, and GS-33, Shark River Slough, Everglades National Park, Florida

$\left[{ }^{\circ} \mathrm{C}\right.$, degrees Celsius; ppt, part per thousand; EDT, Eastern Daylight Time; EST, Eastern Standard Time; ENU, geodetic East North Up; XYZ, Cartesian coordinates]

\begin{tabular}{|c|c|c|c|c|c|c|}
\hline \multirow[b]{2}{*}{ Deployment period ${ }^{1}$} & \multicolumn{2}{|c|}{ Temperature } & \multicolumn{2}{|c|}{ Salinity } & \multicolumn{2}{|c|}{ Coordinate system } \\
\hline & $\begin{array}{c}\text { Old } \\
\left({ }^{\circ} \mathrm{C}\right)\end{array}$ & $\begin{array}{l}\text { New } \\
\left({ }^{\circ} \mathrm{C}\right)\end{array}$ & $\begin{array}{l}\text { Old } \\
\text { (ppt) }\end{array}$ & $\begin{array}{l}\text { New } \\
\text { (ppt) }\end{array}$ & Old & New \\
\hline \multicolumn{7}{|c|}{$\begin{array}{c}\text { SH1 } \\
\text { 2001-2002 wet season }\end{array}$} \\
\hline 08/15/01 $1500-10 / 10 / 011300$ EDT & 25 & 30 & 0.0 & 0.10 & ENU & - \\
\hline 10/11/01 $1130-11 / 06 / 011230$ EDT & 25 & 26 & 0.0 & 0.10 & ENU & - \\
\hline 11/08/01 $1000-01 / 23 / 021500$ EST & 25 & 23 & 0.0 & 0.10 & ENU & - \\
\hline 01/24/02 $1500-02 / 12 / 021230 \mathrm{EST}$ & 25 & 24 & 0.0 & 0.10 & ENU & - \\
\hline
\end{tabular}

GS-203

2001-2002 wet season

\begin{tabular}{|c|c|c|c|c|c|c|}
\hline 08/09/01 1330-08/15/01 1530 EDT & 25 & 31 & 0.0 & 0.17 & $\mathrm{XYZ}$ & ENU \\
\hline 08/16/01 $1100-10 / 10 / 011400$ EDT & 25 & 30 & 0.0 & 0.17 & XYZ & ENU \\
\hline 10/11/02 1030 - 11/06/01 1130 EDT & 25 & 23 & 0.0 & 0.19 & XYZ & ENU \\
\hline 11/08/01 $0900-01 / 23 / 021600$ EST & 25 & 22 & 0.0 & 0.22 & ENU & - \\
\hline 01/24/02 1505 - 02/12/02 1335' EST & 25 & 23 & 0.0 & 0.26 & ENU & - \\
\hline \multicolumn{7}{|c|}{$\begin{array}{c}\text { GS-33 } \\
\text { 2001-2002 wet season }\end{array}$} \\
\hline 08/09/01 1600 - 08/15/01 1530 EDT & 30 & 31 & 0.0 & 0.22 & XYZ & ENU \\
\hline 08/16/01 1000 - 10/10/01 1530 EDT & 30 & 29 & 0.0 & 0.22 & $\mathrm{XYZ}$ & ENU \\
\hline 10/11/01 $1600-11 / 06 / 011000$ EDT & 25 & 25 & 0.0 & 0.22 & ENU & - \\
\hline 11/08/01 $0900-01 / 23 / 021630$ EST & 25 & 22 & 0.0 & 0.26 & ENU & - \\
\hline 01/25/02 0915 - 02/12/02 1445² EST & 25 & 22 & 0.0 & 0.26 & ENU & - \\
\hline
\end{tabular}

${ }^{1}$ Excludes any invalid data segments at beginning and end of deployment record.

${ }^{2}$ Data collection inadvertently initiated at non-multiple time interval.

ics noise of the particular ADV meter used. SNR values are used to verify that particulate matter of appropriate size and concentration was present in the water column to produce a reflected acoustic signal that was sufficiently stronger than the ambient instrument noise. Particulate matter concentrations at the ADV measurement sites yielded average signal amplitudes of 84, 96, and 94 counts at GS-203, GS-33, and SH1, respectively, for all deployments. Ambient instrument noise levels of the ADV units deployed at GS-203, GS-33, and SH1 were 66,72 , and 84 counts, respectively. Thus, average SNR values were approximately $8 \mathrm{~dB}$ (range 5-20 dB) at GS-203, $10 \mathrm{~dB}$ (range 5-25 dB) at GS-33, and $5 \mathrm{~dB}$ (range 2-12 dB) at SH1 during all deployments. Although SNR values were computed for each burst for all ADV deployments, they were not used as a quantitative automated data-editing criterion. Instead, they were used in the qualitative editing processes as a means to evaluate the reliability of data that passed the quantitative filter criterion but were deemed potentially erroneous or suspect in comparison to other flow speeds and directions measured during the deployment period.

Data that passed the preliminary data inspection and validation process were first processed to correct for coordinate-system conversions and sound-speed re-calculations prior to quantitative automated data editing. The initial automated data-editing process consisted of the application of two filter criteria, one based on a minimal statistical correlation for each sample and the other on minimal number of valid samples per burst. A minimum correlation value of 70 percent was used as the statistical-filtering criterion. The number used for the minimum samples-per-burst criterion was determined by examination and assessment of plots of burst-averaged velocities generated using various values of 600, 500, 400, 300, 200, 100 , and 1 (i.e., no minimum) in processing ADV data sets from the SH1, GS-203, and GS-33 sites. As was determined for the 1999-2001 data sets, the 100-minimum filter criterion appeared too inclusive of suspect data and the 300-minimum 
criterion appeared overly exclusive of apparently valid data. Consequently, for the $10-\mathrm{Hz} 1$-minute burst sampling conducted at all three ADV sites, a criterion of 200 was determined to be the most appropriate minimum samples-per-burst filter and it was subsequently used to process all ADV data sets. Differences between daily mean horizontal flow velocities computed using the most liberal criterion, one minimum sample, and all others $(100,200,300,400,500$, and 600) were found to be small in sensitivity tests conducted with past data (Riscassi and Schaffranek, 2002) and data documented in this report. (For the November 2001 through January 2002 deployments at SH1, GS-203, and GS-33, average maximum meandaily velocity differences using all seven samples-per-burst filters were calculated. Average maximum differences of 0.11 , 0.03 , and $0.009 \mathrm{~cm} / \mathrm{s}$ were found with the largest maximum differences being $0.84,0.42$, and $0.10 \mathrm{~cm} / \mathrm{s}$, respectively.)

A secondary qualitative processing technique included the generation of plots of filtered data to detect any remaining anomalous horizontal flow speeds and directions. The qualitative inspection resulted in the removal of 5 percent of velocity bursts from all deployments at $\mathrm{SH} 1$ and 2 percent of velocity bursts from all GS-203 deployments, which included a 14-day period when water levels fell below the transducer of the ADV probe. For all valid deployments at GS-33, 19 percent of the velocity bursts were removed in the qualitative analyses, which included a 9-day period when water levels fell below the transducer of the ADV probe. Bursts that did not pass the qualitative inspection process were deleted and daily mean horizontal-flow speeds and directions were recalculated. The percentages of data that did not pass both the quantitative automated-filter and qualitative-analysis processes for each ADV deployment period are presented with daily mean flow summaries in appendix tables $\mathrm{A}, \mathrm{B}$, and $\mathrm{C}$. The subsequent removal of individual velocity bursts by qualitative analysis did not significantly change the resultant daily mean velocity magnitudes or flow directions.

\section{MicroCAT Conductivity and Temperature Data}

Temperatures measured by the MicroCAT meter near the top of the plant-litter layer at GS-203 and GS-33 were compared to temperatures measured by the thermistor in the temperature string at approximately the same depth in the water column. Good agreement was found for all deployments. No anomalies were found in the MicroCAT temperature data; therefore, the data are made available on the SOFIA website as originally recorded. Daily mean temperatures, derived from data measured by the MicroCAT meters at GS-203 and GS-33, are reported in appendix tables B and C, respectively.

Conductivity data measured by the MicroCAT meter were compared to conductivity measurements taken with a hand-held portable YSI Model 30 meter during field visits. Good agreement was found between the YSI conductivity measurements and MicroCAT data at both GS-203 and GS33 (figs. 3 and 4). No anomalies were found in MicroCAT conductivity data; therefore, the data are made available on the SOFIA website as originally recorded. Daily mean specific conductance values calculated from conductivities recorded at GS-203 and GS-33 are reported in appendix tables B and $\mathrm{C}$, respectively. Conductivity data are recorded in siemens per meter and converted to specific conductance in microsiemens per centimeter $(\mu \mathrm{S} / \mathrm{cm})$ for reporting purposes as documented in Riscassi and Schaffranek (2002).

\section{Thermistor String Temperature Profile Data}

All temperature profile data from the thermistor strings were plotted and inspected for anomalies. Temperatures from the thermistor closest to the height of the MicroCAT probe above the litter layer also were compared to the MicroCAT recorded temperatures. No suspect data were found in the visual inspection or MicroCAT comparisons. Times when all thermistors were out of the water, thus measuring only air temperatures, are identified in table 3 . Temperature profile data documented in this report are available on the SOFIA website.

\section{Flow-Velocity, Conductivity, and Tem- perature Data Summary}

The following report sections summarize the data collected at all four monitoring sites, SH1, GS203, GS33, and NP202, for all deployments during the 2001-2002 wet season. Daily mean flow velocities measured by ADV meters, MicroCAT measured temperatures, and specific conductances derived from MicroCAT measured conductivities are reported in Appendices A, B, and C.

\section{Flow-Velocity Data}

Valid flow-velocity data were not obtained from two ADV deployments at GS-33 during the 2001-2002 wet season. During the first two deployments at GS-33 (table 2), the velocity range setting for the ADV meter reverted to the instrument default of $\pm 250 \mathrm{~cm} / \mathrm{s}$, instead of a more appropriate setting of $\pm 10 \mathrm{~cm} / \mathrm{s}$, making the probe less sensitive to detecting very small velocities. As a consequence, no valid velocity data are available from these two deployments. For the initial deployment at SH1 the ADV meter also defaulted to a \pm 250 $\mathrm{cm} / \mathrm{s}$ range setting, however, the recorded ADV data were not found to be appreciably noisy and were successfully qualitatively filtered to extract a valid set of flow velocities.

Vectors showing velocity magnitudes and flow directions in the horizontal plane, relative to magnetic north, measured during the 2001-2002 wet season at sites SH1, GS-203, and GS-33 are illustrated in figures 5, 6, and 7, respectively. Horizontal velocity magnitudes generally ranged from 0.4 to 2.5 $\mathrm{cm} / \mathrm{s}$ at SH1 (fig. 5), from 0.4 to $1.8 \mathrm{~cm} / \mathrm{s}$ at GS-203 (fig. 6), and from 0.02 to $1.5 \mathrm{~cm} / \mathrm{s}$ at GS-33 (fig. 7). Horizontal flow 
GS-203

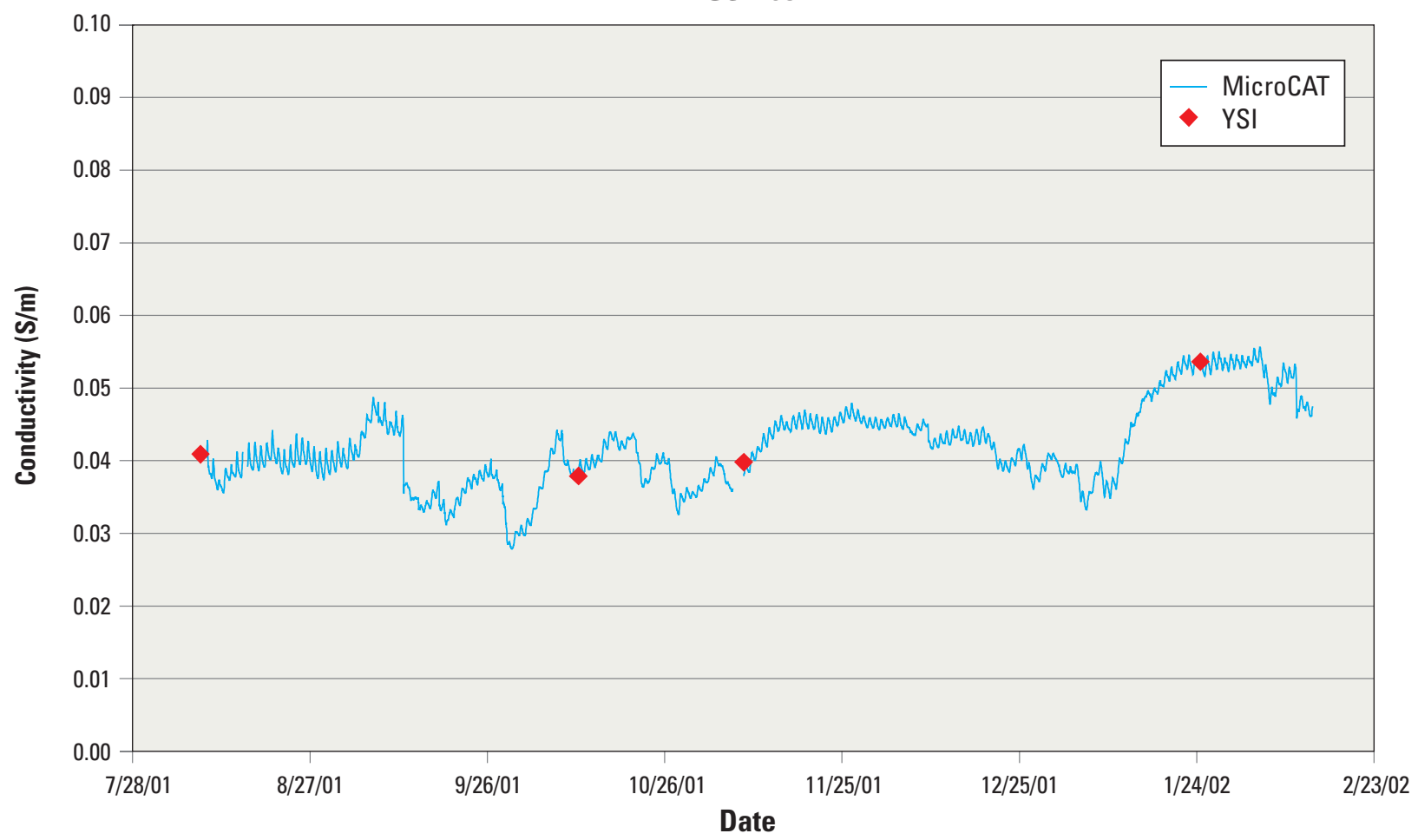

Figure 3. Conductivities measured continuously by MicroCAT probe and intermittently by hand-held YSI meter at GS-203 in Shark River Slough, Everglades National Park, Florida. ( $\mathrm{S} / \mathrm{m}=$ siemens per meter)

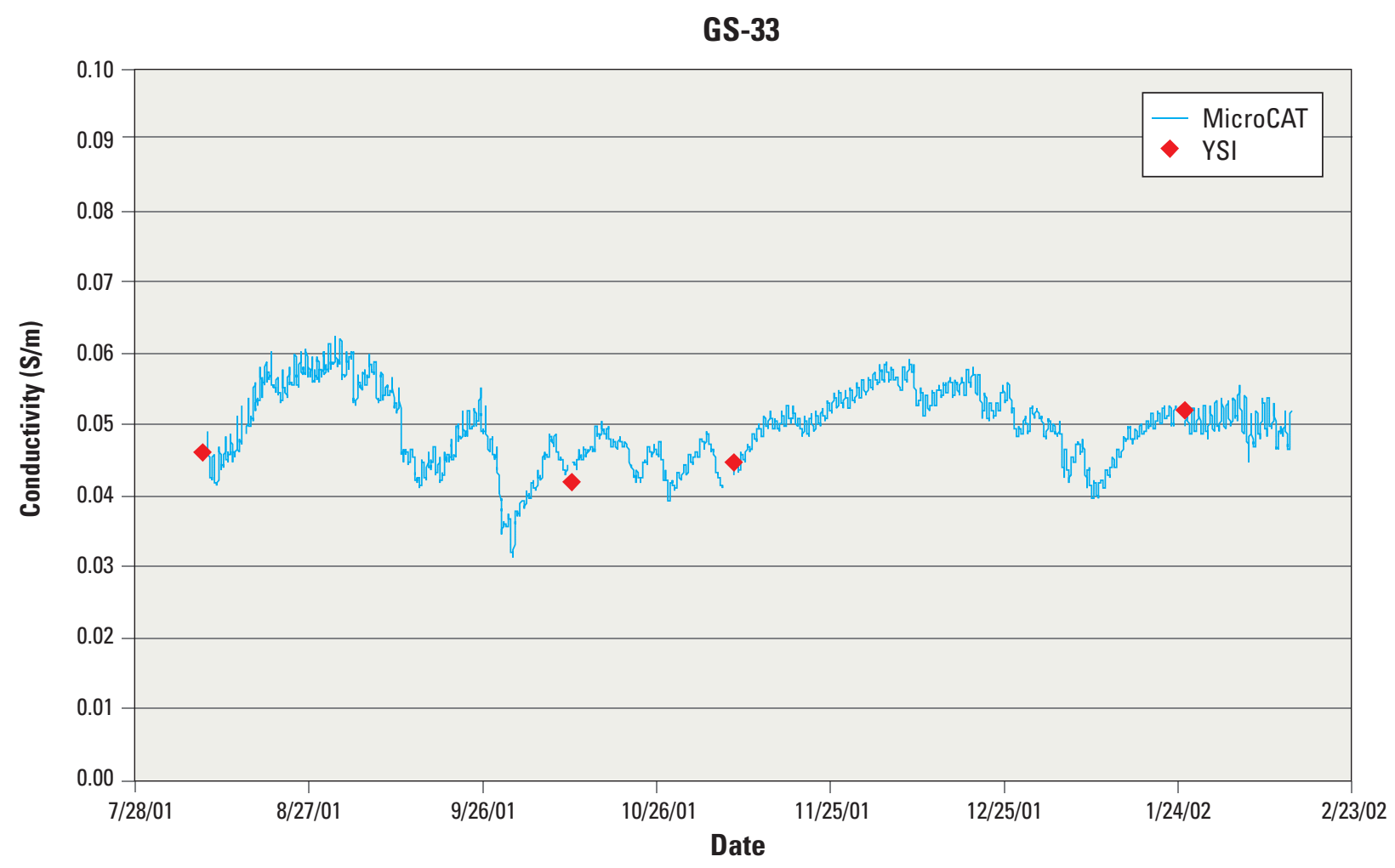

Figure 4. Conductivities measured continuously by MicroCAT probe and intermittently by hand-held YSI meter at GS-33 in Shark River Slough, Everglades National Park, Florida. ( $\mathrm{S} / \mathrm{m}=$ siemens per meter) 


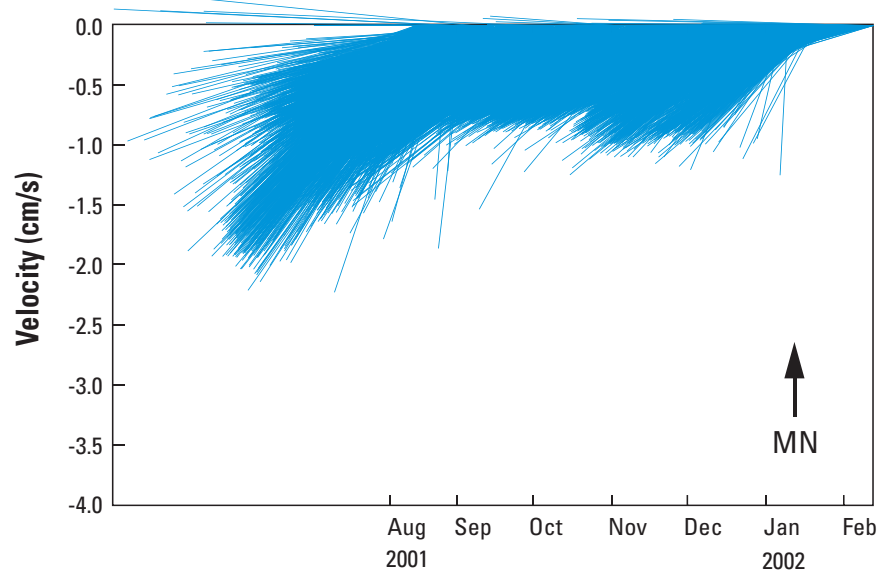

Figure 5. Burst-averaged flow velocities, shown as vectors relative to magnetic north, at SH1 in Shark River Slough, Everglades National Park, Florida, during the 2001-2002 wet season. $(\mathrm{cm} / \mathrm{s}=$ centimeter per second; $\mathrm{MN}$, magnetic north; negative velocity indicates south direction)

directions at all locations generally ranged from 180 to 275 degrees, clockwise with respect to magnetic north (MN). (Declination corrections to Geodetic North are less than the +/- 2 degree accuracy of the ADV compass and, therefore, are not applied to the $\mathrm{MN}$ coordinates reported herein.) Horizontal flow directions averaged approximately 235 degrees at SH1, 251 degrees at GS-203, and 194 degrees at GS-33. Corresponding daily mean horizontal-flow velocities are reported in tabular form for SH1, GS-203, and GS-33 in Appendices A, B, and C, respectively.

\section{Conductivity and Temperature Data}

Specific conductance values, which were calculated from measured conductivities, ranged from approximately 281 to $568 \mu \mathrm{S} / \mathrm{cm}$ at GS-203 and from 315 to $594 \mu \mathrm{S} / \mathrm{cm}$ at GS-33. Water temperatures recorded by the MicroCAT meter near the top of the litter layer ranged from approximately 13 to $36{ }^{\circ} \mathrm{C}$ during all deployments at GS-203 and from 13 to $38^{\circ} \mathrm{C}$ during all deployments at GS-33. During all deployments, temperatures fluctuated several degrees in a daily pattern. Daily mean water temperature and specific conductance values are reported in tabular form for GS-203 and GS-33 in Appendices B and C, respectively.

\section{Temperature Profile Data}

Water-column temperatures measured by the thermistor strings for all deployments at all sites ranged from approximately 11 to $38{ }^{\circ} \mathrm{C}$ in the $2001-2002$ wet season. Daily vertical temperature gradients often approached 3 to $4{ }^{\circ} \mathrm{C}$.

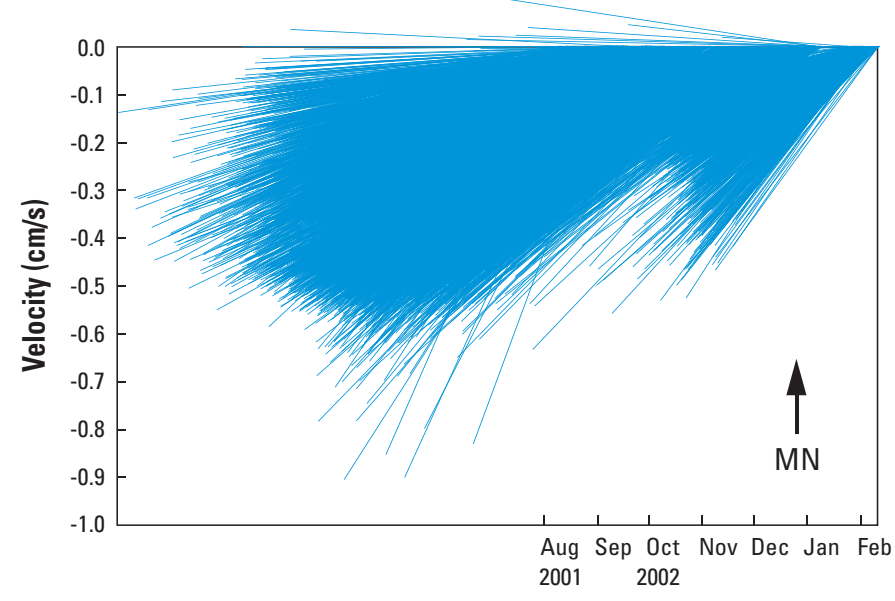

Figure 6. Burst-averaged flow velocities, shown as vectors relative to magnetic north, at GS-203 in Shark River Slough, Everglades National Park, Florida, during the 2001-2002 wet season. $(\mathrm{cm} / \mathrm{s}=$ centimeter per second; $\mathrm{MN}$, magnetic north; negative velocity indicates south direction)

\section{Data Availability}

The quality-checked and edited flow-velocity, water-temperature, and specific-conductance data for the 2001-2002 wet season are available on the World Wide Web. Three-dimensional velocity component data (including associated statistical correlation and SNR values for each component), water-temperature, specific conductance, and water- and air-temperature profile data are available for downloading from the Data Exchange page of the USGS South Florida Information Access (SOFIA) website http: //sofia.usgs.gov. Flow-velocity data also are available for downloading from the Data page of the Tides and Inflows in the Mangroves of the Everglades (TIME) website http: //time.er.usgs.gov.

\section{Summary}

The data-collection effort described in this report is in support of the U.S. Geological Survey (USGS) PlaceBased Studies project to investigate "Forcing Effects on Flow Structure in Vegetated Wetlands of the Everglades." The acquisition, processing, and evaluation of flow-velocity, water-temperature, and conductivity data collected at four locations (sites SH1, GS-203, GS-33, and NP202) in Shark River Slough, Everglades National Park, Florida, during the 2001-2002 wet season are documented in this report. Temperatures were monitored at 5-, 15-, or 30-minute intervals throughout the water column at all four sites, 3-D component flow velocities were monitored bi-hourly at a fixed point in the water column at SH1, GS-203, and GS-33, and conductivities and temperatures were monitored bi-hourly near the 


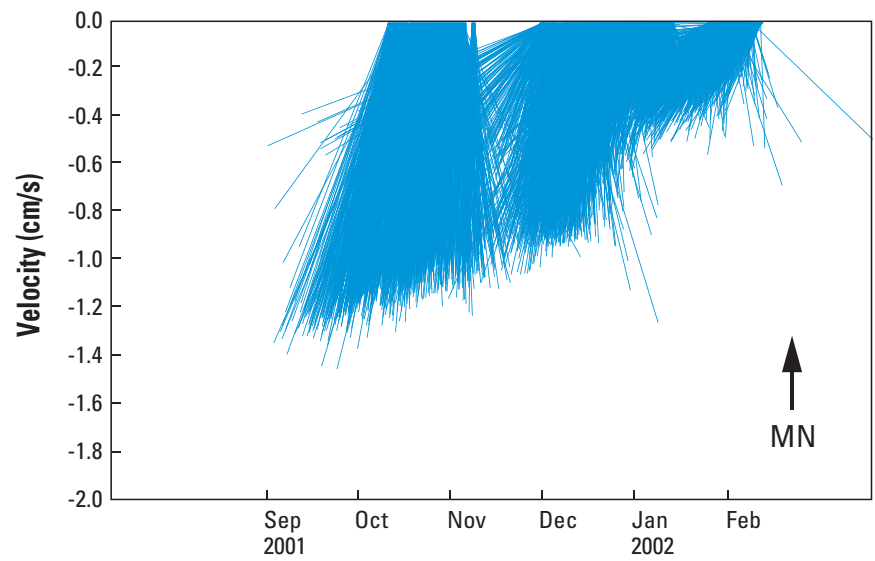

Figure 7. Burst-averaged flow velocities, shown as vectors relative to magnetic north, at GS-33 in Shark River Slough, Everglades National Park, Florida, during the 2001-2002 wet season. $(\mathrm{cm} / \mathrm{s}=$ centimeter per second; $\mathrm{MN}$, magnetic north; negative velocity indicates south direction)

top of the plant-litter layer at GS-203 and GS-33. Velocity vectors defining horizontal flow speeds and directions measured at sites SH1, GS-203, and GS-33 are illustrated in the report. Mean daily horizontal flow velocities, water temperatures, and specific conductance values are listed in tabular form in the report appendices. The quality-checked and edited data have been compiled and stored on the USGS South Florida Information Access (SOFIA) (http://sofia.usgs.gov) and the Tides and Inflows in the Mangroves of the Everglades (TIME) (http: //time.er.usgs.gov) websites.

\section{References Cited}

Ball, M.H., and Schaffranek, R.W., 2000, Flow-velocity data collected in the wetlands adjacent to canal C-111 in south Florida during 1997 and 1999: U.S. Geological Survey Open File Report 00-56, 56 p.

Riscassi, A.L. and Schaffranek, R.W., 2002, Flow velocity, water temperature, and conductivity in Shark River Slough, Everglades National Park, Florida: July 1999 - August 2001: U.S. Geological Survey Open File Report 02-159, $32 \mathrm{p}$.

Sea-Bird Electronics, Inc., 1999, SBE 37-SI MicroCAT conductivity and temperature recorder with RS-232 Interface: User's manual version \# 010, 12/1/99, Bellevue, WA, 41 p.

SonTek, 2001, SonTek ADV acoustic Doppler velocimeter technical documentation: San Diego, CA, 202 p.

Yellow Springs Instruments, 1998, YSI precision thermistors and probes: Yellow Springs, OH, $86 \mathrm{p}$. 


\section{Appendix A}

Daily mean flow velocities and water depths at station SH1, Shark River Slough, Everglades

National Park, Florida during the 2001-2002 wet season. 
Table A - 1. Daily mean flow velocities and water depths at station SH1 during deployment period 08/15/01 150010/10/01 1300

[cm/s, centimeter per second; ${ }^{\circ} \mathrm{CW}$ from $\mathrm{MN}$, degrees clockwise from magnetic north]

\begin{tabular}{|c|c|c|c|}
\hline Date & $\begin{array}{l}\text { Flow velocity }{ }^{1} \\
(\mathrm{~cm} / \mathrm{s})\end{array}$ & $\begin{array}{l}\text { Flow direction }{ }^{1} \\
\left({ }^{\circ} \mathrm{CW} \text { from MN) }\right.\end{array}$ & $\begin{array}{l}\text { Water depth } \\
(\mathrm{cm})\end{array}$ \\
\hline 08/16/01 & 1.72 & 215 & 44 \\
\hline 08/17/01 & 2.01 & 209 & 43 \\
\hline 08/18/01 & 1.76 & 214 & 42 \\
\hline 08/19/01 & 1.70 & 212 & 41 \\
\hline 08/20/01 & 1.82 & 213 & 41 \\
\hline $08 / 21 / 01$ & 2.02 & 211 & 42 \\
\hline 08/22/01 & 2.02 & 211 & 43 \\
\hline $08 / 23 / 01$ & 1.35 & 219 & 44 \\
\hline $08 / 24 / 01$ & 1.28 & 221 & 43 \\
\hline $08 / 25 / 01$ & 1.16 & 226 & 44 \\
\hline 08/26/01 & 1.33 & 222 & 42 \\
\hline $08 / 27 / 01$ & 1.37 & 219 & 41 \\
\hline 08/28/01 & 1.26 & 222 & 41 \\
\hline 08/29/01 & 1.41 & 210 & 42 \\
\hline 08/30/01 & 1.44 & 217 & 41 \\
\hline $08 / 31 / 01$ & 1.45 & 217 & 40 \\
\hline 09/01/01 & 1.57 & 214 & 39 \\
\hline 09/02/01 & 1.56 & 213 & 39 \\
\hline 09/03/01 & 1.45 & 212 & 39 \\
\hline 09/04/01 & 1.25 & 225 & 38 \\
\hline 09/05/01 & 1.03 & 239 & 38 \\
\hline 09/06/01 & 1.13 & 239 & 39 \\
\hline 09/07/01 & 1.11 & 233 & 40 \\
\hline 09/08/01 & 1.06 & 231 & 41 \\
\hline 09/09/01 & 1.26 & 226 & 41 \\
\hline 09/10/01 & 1.35 & 221 & 42 \\
\hline 09/11/01 & 1.27 & 229 & 44 \\
\hline 09/12/01 & 1.22 & 230 & 46 \\
\hline 09/13/01 & 1.15 & 228 & 48 \\
\hline 09/14/01 & 1.32 & 232 & 51 \\
\hline $09 / 15 / 01$ & 1.29 & 240 & 53 \\
\hline
\end{tabular}


Table A-1. Daily mean flow velocities and water depths at station SH1 during deployment period 08/15/01 150010/10/01 1300 - Continued

[cm/s, centimeter per second; ${ }^{\circ} \mathrm{CW}$ from $\mathrm{MN}$, degrees clockwise from magnetic north]

\begin{tabular}{|c|c|c|c|}
\hline Date & $\begin{array}{l}\text { Flow velocity }{ }^{1} \\
\text { (cm/s) }\end{array}$ & $\begin{array}{l}\text { Flow direction' } \\
\text { ( }{ }^{\circ} \mathrm{CW} \text { from MN) }\end{array}$ & $\begin{array}{l}\text { Water depth } \\
\text { (cm) }\end{array}$ \\
\hline 09/16/01 & 1.38 & 244 & 54 \\
\hline 09/17/01 & 1.51 & 235 & 54 \\
\hline 09/18/01 & 1.44 & 235 & 55 \\
\hline 09/19/01 & 1.44 & 237 & 55 \\
\hline 09/20/01 & 1.43 & 236 & 55 \\
\hline $09 / 21 / 01$ & 1.42 & 238 & 56 \\
\hline $09 / 22 / 01$ & 1.42 & 236 & 56 \\
\hline $09 / 23 / 01$ & 1.40 & 237 & 56 \\
\hline $09 / 24 / 01$ & 1.42 & 238 & 57 \\
\hline $09 / 25 / 01$ & 1.33 & 236 & 57 \\
\hline $09 / 26 / 01$ & 1.35 & 236 & 57 \\
\hline $09 / 27 / 01$ & 1.27 & 241 & 57 \\
\hline $09 / 28 / 01$ & 1.20 & 230 & 57 \\
\hline 09/29/01 & 1.42 & 242 & 66 \\
\hline 09/30/01 & 1.41 & 245 & 69 \\
\hline $10 / 01 / 01$ & 1.32 & 250 & 69 \\
\hline $10 / 02 / 01$ & 1.34 & 249 & 68 \\
\hline $10 / 03 / 01$ & 1.43 & 247 & 68 \\
\hline $10 / 04 / 01$ & 1.37 & 246 & 67 \\
\hline $10 / 05 / 01$ & 1.28 & 243 & 66 \\
\hline $10 / 06 / 01$ & 1.30 & 241 & 65 \\
\hline $10 / 07 / 01$ & 1.28 & 241 & 65 \\
\hline $10 / 08 / 01$ & 1.31 & 239 & 64 \\
\hline $10 / 09 / 01$ & $*$ & $*$ & 63 \\
\hline \multicolumn{4}{|l|}{ * All bursts filtered out } \\
\hline MINIMUM & 1.03 & 209 & 38 \\
\hline MAXIMUM & 2.02 & 250 & 69 \\
\hline AVERAGE & 1.40 & 229 & 50 \\
\hline $\begin{array}{l}\text { BURSTS FILTERED } \\
\text { OUT }(\%)\end{array}$ & 5 & & \\
\hline
\end{tabular}

\footnotetext{
${ }^{1}$ Flow sample volume located $22 \mathrm{~cm}$ above top of litter.
} 
Table A-2. Daily mean flow velocities and water depths at station SH1 during deployment period $10 / 11 / 011130-11 / 06 / 011230$

[cm/s, centimeter per second; ${ }^{\circ} \mathrm{CW}$ from $\mathrm{MN}$, degrees clockwise from magnetic north]

\begin{tabular}{|c|c|c|c|}
\hline Date & $\begin{array}{c}\text { Flow velocity' } \\
\text { (cm/s) }\end{array}$ & $\begin{array}{l}\text { Flow direction }{ }^{1} \\
\left({ }^{\circ} \mathrm{CW} \text { from MN) }\right.\end{array}$ & $\begin{array}{l}\text { Water depth } \\
\text { (cm) }\end{array}$ \\
\hline $10 / 12 / 01$ & 1.35 & 238 & 61 \\
\hline $10 / 13 / 01$ & 1.29 & 238 & 60 \\
\hline $10 / 14 / 01$ & 1.27 & 240 & 60 \\
\hline $10 / 15 / 01$ & 1.51 & 230 & 59 \\
\hline $10 / 16 / 01$ & 1.50 & 229 & 59 \\
\hline $10 / 17 / 01$ & 1.45 & 231 & 58 \\
\hline $10 / 18 / 01$ & 1.49 & 230 & 57 \\
\hline $10 / 19 / 01$ & 1.59 & 229 & 57 \\
\hline $10 / 20 / 01$ & 1.33 & 238 & 57 \\
\hline $10 / 21 / 01$ & 1.40 & 239 & 58 \\
\hline $10 / 22 / 01$ & 1.29 & 246 & 63 \\
\hline $10 / 23 / 01$ & 1.30 & 247 & 64 \\
\hline $10 / 24 / 01$ & 1.29 & 248 & 64 \\
\hline $10 / 25 / 01$ & 1.32 & 244 & 65 \\
\hline $10 / 26 / 01$ & 1.39 & 244 & 65 \\
\hline $10 / 27 / 01$ & 1.39 & 242 & 64 \\
\hline $10 / 28 / 01$ & 0.98 & 241 & 64 \\
\hline $10 / 29 / 01$ & 1.05 & 245 & 63 \\
\hline $10 / 30 / 01$ & 0.94 & 243 & 63 \\
\hline $10 / 31 / 01$ & 0.73 & 240 & 63 \\
\hline $11 / 01 / 01$ & 0.79 & 251 & 62 \\
\hline $11 / 02 / 01$ & 0.98 & 252 & 61 \\
\hline $11 / 03 / 01$ & 1.14 & 244 & 61 \\
\hline $11 / 04 / 01$ & 1.25 & 239 & 61 \\
\hline $11 / 05 / 01$ & 1.31 & 241 & 61 \\
\hline MINIMUM & 0.73 & 229 & 57 \\
\hline MAXIMUM & 1.59 & 252 & 65 \\
\hline AVERAGE & 1.25 & 240 & 61 \\
\hline $\begin{array}{l}\text { BURSTS FILTERED } \\
\text { OUT }(\%)\end{array}$ & 5 & & \\
\hline
\end{tabular}

\footnotetext{
${ }^{1}$ Flow sample volume located $22 \mathrm{~cm}$ above top of litter.
} 
Table A - 3. Daily mean flow velocities and water depths at station SH1 during deployment period $11 / 08 / 011000-01 / 23 / 021500$

[cm/s, centimeter per second; ${ }^{\circ} \mathrm{CW}$ from $\mathrm{MN}$, degrees clockwise from magnetic north]

\begin{tabular}{|c|c|c|c|}
\hline Date & $\begin{array}{l}\text { Flow velocity' } \\
(\mathrm{cm} / \mathrm{s})\end{array}$ & $\begin{array}{l}\text { Flow direction }{ }^{1} \\
\left({ }^{\circ} \mathrm{CW} \text { from } \mathrm{MN}\right)\end{array}$ & $\begin{array}{l}\text { Water depth } \\
\text { (cm) }\end{array}$ \\
\hline $11 / 09 / 01$ & 1.43 & 237 & 58 \\
\hline $11 / 10 / 01$ & 1.34 & 236 & 58 \\
\hline $11 / 11 / 01$ & 1.40 & 238 & 57 \\
\hline $11 / 12 / 01$ & 1.38 & 238 & 56 \\
\hline $11 / 13 / 01$ & 1.34 & 237 & 56 \\
\hline $11 / 14 / 01$ & 1.30 & 236 & 55 \\
\hline $11 / 15 / 01$ & 1.30 & 235 & 54 \\
\hline $11 / 16 / 01$ & 1.30 & 236 & 54 \\
\hline $11 / 17 / 01$ & 1.28 & 235 & 53 \\
\hline $11 / 18 / 01$ & 1.20 & 232 & 53 \\
\hline $11 / 19 / 01$ & 1.20 & 231 & 52 \\
\hline $11 / 20 / 01$ & 1.19 & 232 & 52 \\
\hline $11 / 21 / 01$ & 1.17 & 235 & 52 \\
\hline $11 / 22 / 01$ & 1.14 & 233 & 51 \\
\hline $11 / 23 / 01$ & 1.19 & 236 & 51 \\
\hline $11 / 24 / 01$ & 1.18 & 236 & 50 \\
\hline $11 / 25 / 01$ & 1.13 & 234 & 50 \\
\hline $11 / 26 / 01$ & 1.20 & 237 & 49 \\
\hline $11 / 27 / 01$ & 1.23 & 239 & 48 \\
\hline $11 / 28 / 01$ & 1.23 & 239 & 48 \\
\hline $11 / 29 / 01$ & 1.29 & 238 & 48 \\
\hline $11 / 30 / 01$ & 1.27 & 237 & 47 \\
\hline $12 / 01 / 01$ & 1.22 & 235 & 47 \\
\hline $12 / 02 / 01$ & 1.28 & 236 & 47 \\
\hline $12 / 03 / 01$ & 1.24 & 233 & 47 \\
\hline $12 / 04 / 01$ & 1.22 & 233 & 46 \\
\hline $12 / 05 / 01$ & 1.23 & 234 & 46 \\
\hline $12 / 06 / 01$ & 1.26 & 234 & 46 \\
\hline $12 / 07 / 01$ & 1.25 & 235 & 46 \\
\hline $12 / 08 / 01$ & 1.22 & 234 & 46 \\
\hline $12 / 09 / 01$ & 1.41 & 236 & 48 \\
\hline $12 / 10 / 01$ & 1.61 & 241 & 54 \\
\hline
\end{tabular}


Table A - 3. Daily mean flow velocities and water depths at station SH1 during deployment period 11/08/01 $1000-01 / 23 / 021500$ - Continued

[cm/s, centimeter per second; ${ }^{\circ} \mathrm{CW}$ from $\mathrm{MN}$, degrees clockwise from magnetic north]

\begin{tabular}{|c|c|c|c|}
\hline Date & $\begin{array}{l}\text { Flow velocity' } \\
\text { (cm/s) }\end{array}$ & $\begin{array}{l}\text { Flow direction }{ }^{1} \\
\left({ }^{\circ} \mathrm{CW} \text { from } \mathrm{MN}\right)\end{array}$ & $\begin{array}{l}\text { Water depth } \\
\text { (cm) }\end{array}$ \\
\hline $12 / 11 / 01$ & 1.50 & 240 & 54 \\
\hline $12 / 12 / 01$ & 1.42 & 239 & 54 \\
\hline $12 / 13 / 01$ & 1.39 & 237 & 54 \\
\hline $12 / 14 / 01$ & 1.31 & 241 & 54 \\
\hline $12 / 15 / 01$ & 1.19 & 246 & 53 \\
\hline $12 / 16 / 01$ & 1.23 & 245 & 52 \\
\hline $12 / 17 / 01$ & 1.28 & 239 & 51 \\
\hline $12 / 18 / 01$ & 1.23 & 237 & 51 \\
\hline $12 / 19 / 01$ & 1.22 & 236 & 50 \\
\hline $12 / 20 / 01$ & 1.14 & 234 & 52 \\
\hline $12 / 21 / 01$ & 1.14 & 234 & 53 \\
\hline $12 / 22 / 01$ & 1.08 & 232 & 52 \\
\hline $12 / 23 / 01$ & 1.13 & 228 & 52 \\
\hline $12 / 24 / 01$ & 1.11 & 230 & 51 \\
\hline $12 / 25 / 01$ & 1.25 & 226 & 51 \\
\hline $12 / 26 / 01$ & 0.97 & 229 & 51 \\
\hline $12 / 27 / 01$ & 1.21 & 223 & 50 \\
\hline $12 / 28 / 01$ & 1.24 & 220 & 50 \\
\hline $12 / 29 / 01$ & 1.16 & 221 & 49 \\
\hline $12 / 30 / 01$ & 1.02 & 224 & 49 \\
\hline $12 / 31 / 01$ & 1.09 & 228 & 49 \\
\hline 01/01/02 & 0.96 & 229 & 49 \\
\hline $01 / 02 / 02$ & 0.94 & 242 & 51 \\
\hline 01/03/02 & 0.91 & 239 & 54 \\
\hline
\end{tabular}


Table A - 3. Daily mean flow velocities and water depths at station SH1 during deployment period 11/08/01 $1000-01 / 23 / 021500$ - Continued

$\left[\mathrm{cm} / \mathrm{s}\right.$, centimeter per second; ${ }^{\circ} \mathrm{CW}$ from $\mathrm{MN}$, degrees clockwise from magnetic north]

\begin{tabular}{|c|c|c|c|}
\hline Date & $\begin{array}{l}\text { Flow velocity }{ }^{1} \\
\qquad(\mathrm{~cm} / \mathrm{s})\end{array}$ & $\begin{array}{l}\text { Flow direction' } \\
\text { ( }{ }^{\circ} \mathrm{CW} \text { from MN) }\end{array}$ & $\begin{array}{l}\text { Water depth } \\
\text { (cm) }\end{array}$ \\
\hline $01 / 04 / 02$ & 1.28 & 247 & 53 \\
\hline $01 / 05 / 02$ & 1.00 & 246 & 52 \\
\hline 01/06/02 & 0.80 & 246 & 51 \\
\hline $01 / 07 / 02$ & 0.77 & 233 & 51 \\
\hline $01 / 08 / 02$ & 0.84 & 228 & 50 \\
\hline $01 / 09 / 02$ & 0.81 & 234 & 49 \\
\hline $01 / 10 / 02$ & 0.88 & 235 & 49 \\
\hline $01 / 11 / 02$ & 0.82 & 238 & 48 \\
\hline $01 / 12 / 02$ & 0.80 & 242 & 47 \\
\hline $01 / 13 / 02$ & 0.85 & 232 & 47 \\
\hline $01 / 14 / 02$ & 0.83 & 229 & 46 \\
\hline $01 / 15 / 02$ & 0.85 & 240 & 46 \\
\hline $01 / 16 / 02$ & 0.82 & 236 & 45 \\
\hline $01 / 17 / 02$ & 1.00 & 234 & 45 \\
\hline $01 / 18 / 02$ & 1.14 & 230 & 44 \\
\hline $01 / 19 / 02$ & 1.32 & 237 & 43 \\
\hline $01 / 20 / 02$ & 1.18 & 221 & 43 \\
\hline $01 / 21 / 02$ & 1.25 & 224 & 42 \\
\hline $01 / 22 / 02$ & 1.25 & 226 & 42 \\
\hline MINIMUM & 0.77 & 220 & 42 \\
\hline MAXIMUM & 1.61 & 247 & 58 \\
\hline AVERAGE & 1.16 & 235 & 50 \\
\hline BURSTS FILTERED OUT $(\%)$ & 3 & & \\
\hline
\end{tabular}

${ }^{1}$ Flow sample volume located $22 \mathrm{~cm}$ above top of litter. 
Table A - 4. Daily mean flow velocities and water depths at station SH1 during deployment period 01/24/02 $1500-02 / 12 / 021230$

[cm/s, centimeter per second; ${ }^{\circ} \mathrm{CW}$ from $\mathrm{MN}$, degrees clockwise from magnetic north ]

\begin{tabular}{|c|c|c|c|}
\hline Date & $\begin{array}{l}\text { Flow velocity }{ }^{1} \\
\qquad(\mathrm{~cm} / \mathrm{s})\end{array}$ & $\begin{array}{l}\text { Flow direction' } \\
\left({ }^{\circ} \mathrm{CW} \text { from MN) }\right.\end{array}$ & $\begin{array}{l}\text { Water depth } \\
\text { (cm) }\end{array}$ \\
\hline $01 / 25 / 02$ & 1.10 & 248 & 40 \\
\hline $01 / 26 / 02$ & 1.04 & 251 & 39 \\
\hline $01 / 27 / 02$ & 1.03 & 245 & 39 \\
\hline $01 / 28 / 02$ & 1.03 & 247 & 38 \\
\hline $01 / 29 / 02$ & 0.93 & 245 & 37 \\
\hline 01/30/02 & 1.01 & 244 & 37 \\
\hline $01 / 31 / 02$ & 1.14 & 249 & 36 \\
\hline $02 / 01 / 02$ & 1.34 & 250 & 36 \\
\hline $02 / 02 / 02$ & 1.23 & 244 & 35 \\
\hline $02 / 03 / 02$ & 1.36 & 251 & 35 \\
\hline $02 / 04 / 02$ & 1.48 & 256 & 34 \\
\hline $02 / 05 / 02$ & 1.45 & 255 & 34 \\
\hline $02 / 06 / 02$ & 1.18 & 260 & 33 \\
\hline 02/07/02 & $*$ & $*$ & 32 \\
\hline $02 / 08 / 02$ & 1.42 & 255 & 32 \\
\hline $02 / 09 / 02$ & 1.56 & 261 & 32 \\
\hline $02 / 10 / 02$ & 1.54 & 264 & 33 \\
\hline $02 / 11 / 02$ & 1.41 & 261 & 33 \\
\hline \multicolumn{4}{|l|}{ * all bursts filtered out } \\
\hline MINIMUM & 0.93 & 244 & 32 \\
\hline MAXIMUM & 1.56 & 264 & 40 \\
\hline AVERAGE & 1.25 & 252 & 35 \\
\hline $\begin{array}{l}\text { BURSTS FILTERED } \\
\text { OUT }(\%)\end{array}$ & 13 & & \\
\hline
\end{tabular}

${ }^{1}$ Flow sample volume located $22 \mathrm{~cm}$ above top of litter. 


\section{Appendix B}

Daily mean flow velocities, water-temperatures, specific conductances, and water depths at station GS-203, Shark River Slough, Everglades National Park, Florida during the 2001-2002 wet season. 
Table B -1. Daily mean flow velocities, MicroCAT water temperatures and specific conductances, and water depths at station GS-203 during deployment period 08/09/01 $1330-08 / 15 / 011530$

$\left[\mathrm{cm} / \mathrm{s}\right.$, centimeter per second; ${ }^{\circ} \mathrm{CW}$ from $\mathrm{MN}$, degrees clockwise from magnetic north; ${ }^{\circ} \mathrm{C}$, degrees Celsius; $\mu \mathrm{S} / \mathrm{cm}$, microsiemens per centimeter]

\begin{tabular}{|c|c|c|c|c|c|}
\hline Date & $\begin{array}{l}\text { Flow velocity }{ }^{1} \\
\qquad(\mathrm{~cm} / \mathrm{s})\end{array}$ & $\begin{array}{l}\text { Flow direction' } \\
\text { ( }{ }^{\circ} \mathrm{CW} \text { from MN) }\end{array}$ & $\begin{array}{c}\text { Temperature }{ }^{2} \\
\left({ }^{\circ} \mathrm{C}\right)\end{array}$ & $\begin{array}{c}\text { Specific } \\
\text { conductance }^{2} \\
(\mu \mathrm{S} / \mathrm{cm})\end{array}$ & $\begin{array}{l}\text { Water depth } \\
\text { (cm) }\end{array}$ \\
\hline 08/10/01 & 1.08 & 251 & 31.01 & 342 & 29 \\
\hline 08/11/01 & 0.94 & 247 & 30.43 & 331 & 28 \\
\hline 08/12/01 & 0.88 & 241 & 31.06 & 330 & 28 \\
\hline 08/13/01 & 0.95 & 248 & 31.46 & 337 & 27 \\
\hline 08/14/01 & 1.07 & 251 & 32.25 & 340 & 27 \\
\hline MINIMUM & 0.88 & 241 & 30.43 & 330 & 27 \\
\hline MAXIMUM & 1.08 & 251 & 32.25 & 342 & 29 \\
\hline AVERAGE & 0.99 & 248 & 31.24 & 336 & 28 \\
\hline $\begin{array}{l}\text { BURSTS FILTERED } \\
\text { OUT }(\%)\end{array}$ & 0 & & 0 & 0 & \\
\hline
\end{tabular}

${ }^{1}$ Flow sample volume located $15 \mathrm{~cm}$ above top of litter.

${ }^{2}$ MicroCAT temperature and conductance measured $13 \mathrm{~cm}$ above top of litter. 
Table B -2. Daily mean flow velocities, MicroCAT water temperatures and specific conductances, and water depths at station GS-203 during deployment period 08/16/01 1100 - 10/10/01 1400

$\left[\mathrm{cm} / \mathrm{s}\right.$, centimeter per second; ${ }^{\circ} \mathrm{CW}$ from MN, degrees clockwise from magnetic north; ${ }^{\circ} \mathrm{C}$, degrees Celsius; $\mu \mathrm{S} / \mathrm{cm}$, microsiemens per centimeter]

\begin{tabular}{|c|c|c|c|c|c|}
\hline Date & $\begin{array}{l}\text { Flow velocity' } \\
\quad(\mathrm{cm} / \mathrm{s})\end{array}$ & $\begin{array}{l}\text { Flow direction }{ }^{1} \\
\left({ }^{\circ} \mathrm{CW} \text { from } \mathrm{MN}\right)\end{array}$ & $\begin{array}{c}\text { Temperature }{ }^{2} \\
\left({ }^{\circ} \mathrm{C}\right)\end{array}$ & $\begin{array}{c}\text { Specific } \\
\text { conductance }{ }^{2} \\
(\mu \mathrm{S} / \mathrm{cm})\end{array}$ & $\begin{array}{l}\text { Water depth } \\
\quad \text { (cm) }\end{array}$ \\
\hline 08/17/01 & 1.02 & 251 & 32.84 & 347 & 28 \\
\hline 08/18/01 & 0.97 & 251 & 32.94 & 346 & 27 \\
\hline 08/19/01 & 0.95 & 249 & 32.73 & 351 & 27 \\
\hline 08/20/01 & 0.94 & 248 & 32.25 & 362 & 27 \\
\hline $08 / 21 / 01$ & 0.97 & 248 & 30.36 & 366 & 28 \\
\hline 08/22/01 & 0.97 & 248 & 29.55 & 361 & 29 \\
\hline 08/23/01 & 0.95 & 247 & 30.58 & 358 & 29 \\
\hline $08 / 24 / 01$ & 1.02 & 251 & 31.75 & 360 & 29 \\
\hline 08/25/01 & 1.17 & 256 & 32.32 & 358 & 29 \\
\hline 08/26/01 & 1.01 & 253 & 32.62 & 354 & 29 \\
\hline 08/27/01 & 0.93 & 252 & 32.13 & 349 & 29 \\
\hline 08/28/01 & 0.88 & 249 & 31.83 & 343 & 29 \\
\hline 08/29/01 & 0.88 & 248 & 32.00 & 344 & 29 \\
\hline 08/30/01 & 0.87 & 247 & 32.02 & 347 & 29 \\
\hline 08/31/01 & 0.87 & 248 & 32.15 & 351 & 29 \\
\hline 09/01/01 & 0.85 & 246 & 31.61 & 355 & 29 \\
\hline 09/02/01 & 0.90 & 248 & 31.45 & 360 & 30 \\
\hline 09/03/01 & 0.88 & 250 & 30.93 & 367 & 30 \\
\hline 09/04/01 & 0.88 & 250 & 30.41 & 380 & 31 \\
\hline 09/05/01 & 0.81 & 249 & 30.91 & 399 & 31 \\
\hline 09/06/01 & 0.83 & 250 & 30.88 & 418 & 31 \\
\hline 09/07/01 & 0.91 & 253 & 29.63 & 424 & 32 \\
\hline 09/08/01 & 0.95 & 255 & 29.07 & 425 & 33 \\
\hline 09/09/01 & 0.91 & 255 & 28.55 & 416 & 34 \\
\hline 09/10/01 & 0.95 & 256 & 28.38 & 417 & 34 \\
\hline 09/11/01 & 0.94 & 256 & 28.44 & 405 & 37 \\
\hline 09/12/01 & 1.12 & 262 & 27.57 & 347 & 44 \\
\hline
\end{tabular}


Table B -2. Daily mean flow velocities, MicroCAT water temperatures and specific conductances, and water depths at station GS-203 during deployment period 08/16/01 1100 - 10/10/01 1400 — Continued

$\left[\mathrm{cm} / \mathrm{s}\right.$, centimeter per second; ${ }^{\circ} \mathrm{CW}$ from $\mathrm{MN}$, degrees clockwise from magnetic north; ${ }^{\circ} \mathrm{C}$, degrees Celsius; $\mu \mathrm{S} / \mathrm{cm}$, microsiemens per centimeter]

\begin{tabular}{|c|c|c|c|c|c|}
\hline Date & $\begin{array}{l}\text { Flow velocity' } \\
\qquad(\mathrm{cm} / \mathrm{s})\end{array}$ & $\begin{array}{l}\text { Flow direction }{ }^{1} \\
\left({ }^{\circ} \mathrm{CW} \text { from } \mathrm{MN}\right)\end{array}$ & $\begin{array}{l}\text { Temperature }{ }^{2} \\
\quad\left({ }^{\circ} \mathrm{C}\right)\end{array}$ & $\begin{array}{c}\text { Specific } \\
\text { conductance }{ }^{2} \\
(\mu \mathrm{S} / \mathrm{cm})\end{array}$ & $\begin{array}{l}\text { Water depth } \\
\quad \text { (cm) }\end{array}$ \\
\hline 09/13/01 & 0.94 & 257 & 27.20 & 333 & 43 \\
\hline 09/14/01 & 1.00 & 251 & 26.80 & 328 & 45 \\
\hline 09/15/01 & 1.07 & 261 & 27.23 & 322 & 45 \\
\hline 09/16/01 & 1.08 & 261 & 28.09 & 325 & 44 \\
\hline 09/17/01 & 1.08 & 259 & 29.49 & 326 & 43 \\
\hline 09/18/01 & 1.07 & 256 & 29.75 & 305 & 45 \\
\hline 09/19/01 & 0.90 & 251 & 29.16 & 298 & 46 \\
\hline 09/20/01 & 0.87 & 248 & 29.69 & 306 & 45 \\
\hline 09/21/01 & 0.87 & 249 & 30.54 & 315 & 44 \\
\hline 09/22/01 & 0.87 & 247 & 30.85 & 327 & 43 \\
\hline 09/23/01 & 0.86 & 249 & 30.69 & 334 & 42 \\
\hline 09/24/01 & 0.85 & 247 & 31.02 & 337 & 42 \\
\hline 09/25/01 & 0.84 & 250 & 31.23 & 340 & 41 \\
\hline 09/26/01 & 0.90 & 254 & 30.53 & 346 & 41 \\
\hline 09/27/01 & 0.98 & 256 & 28.68 & 351 & 42 \\
\hline 09/28/01 & 1.02 & 254 & 27.02 & 340 & 44 \\
\hline 09/29/01 & 1.28 & 261 & 25.18 & 295 & 54 \\
\hline 09/30/01 & 1.17 & 259 & 25.49 & 286 & 55 \\
\hline $10 / 01 / 01$ & 1.07 & 257 & 26.16 & 296 & 54 \\
\hline $10 / 02 / 01$ & 1.02 & 258 & 26.29 & 299 & 53 \\
\hline $10 / 03 / 01$ & 0.95 & 254 & 26.68 & 311 & 53 \\
\hline $10 / 04 / 01$ & 0.91 & 253 & 27.37 & 331 & 54 \\
\hline $10 / 05 / 01$ & 0.90 & 252 & 28.01 & 351 & 53 \\
\hline $10 / 06 / 01$ & 0.81 & 251 & 29.30 & 368 & 53 \\
\hline $10 / 07 / 01$ & 0.79 & 250 & 30.73 & 379 & 52 \\
\hline $10 / 08 / 01$ & 0.90 & 253 & 30.31 & 385 & 52 \\
\hline $10 / 09 / 01$ & 0.96 & 252 & 28.01 & 372 & 53 \\
\hline MINIMUM & 0.79 & 246 & 25.18 & 286 & 27 \\
\hline MAXIMUM & 1.28 & 262 & 32.94 & 425 & 55 \\
\hline AVERAGE & 0.95 & 252 & 29.77 & 350 & 39 \\
\hline $\begin{array}{l}\text { BURSTS FILTERED } \\
\text { OUT }(\%)\end{array}$ & 0 & & 0 & 0 & \\
\hline
\end{tabular}

${ }^{1}$ Flow sample volume located $15 \mathrm{~cm}$ above top of litter.

${ }^{2}$ MicroCAT temperature and conductance measured $13 \mathrm{~cm}$ above top of litter. 
Table B - 3. Daily mean flow velocities, MicroCAT water temperatures and specific conductances, and water depths at station GS-203 during deployment period 10/11/02 1030 - 11/06/01 1130

$\left[\mathrm{cm} / \mathrm{s}\right.$, centimeter per second; ${ }^{\circ} \mathrm{CW}$ from $\mathrm{MN}$, degrees clockwise from magnetic north; ${ }^{\circ} \mathrm{C}$, degrees Celsius; $\mu \mathrm{S} / \mathrm{cm}$, microsiemens per centimeter]

\begin{tabular}{|c|c|c|c|c|c|}
\hline Date & $\begin{array}{l}\text { Flow velocity' } \\
\text { (cm/s) }\end{array}$ & $\begin{array}{l}\text { Flow direction }{ }^{1} \\
\left({ }^{\circ} \mathrm{CW} \text { from MN) }\right.\end{array}$ & $\begin{array}{l}\text { Temperature }^{2} \\
\left({ }^{\circ} \mathrm{C}\right)\end{array}$ & $\begin{array}{c}\text { Specific } \\
\text { conductance } \\
(\mu \mathrm{S} / \mathrm{cm})\end{array}$ & $\begin{array}{l}\text { Water depth } \\
\quad \text { (cm) }\end{array}$ \\
\hline $10 / 12 / 01$ & 1.22 & 248 & 27.23 & 374 & 51 \\
\hline 10/13/01 & 1.19 & 246 & 27.07 & 381 & 51 \\
\hline 10/14/01 & 1.17 & 246 & 27.05 & 384 & 51 \\
\hline $10 / 15 / 01$ & 1.18 & 247 & 27.78 & 390 & 50 \\
\hline 10/16/01 & 1.16 & 245 & 28.67 & 399 & 50 \\
\hline 10/17/01 & 1.26 & 247 & 28.12 & 408 & 50 \\
\hline $10 / 18 / 01$ & 1.28 & 248 & 25.97 & 413 & 50 \\
\hline 10/19/01 & 1.27 & 248 & 26.08 & 415 & 51 \\
\hline 10/20/01 & 1.28 & 248 & 26.37 & 421 & 52 \\
\hline $10 / 21 / 01$ & 1.35 & 247 & 25.80 & 400 & 56 \\
\hline $10 / 22 / 01$ & 1.43 & 250 & 26.19 & 361 & 61 \\
\hline $10 / 23 / 01$ & 1.34 & 249 & 27.55 & 360 & 60 \\
\hline $10 / 24 / 01$ & 1.29 & 248 & 28.77 & 369 & 60 \\
\hline $10 / 25 / 01$ & 1.29 & 247 & 29.45 & 368 & 59 \\
\hline $10 / 26 / 01$ & 1.43 & 251 & 28.81 & 367 & 59 \\
\hline $10 / 27 / 01$ & 1.51 & 252 & 23.76 & 367 & 58 \\
\hline $10 / 28 / 01$ & 1.46 & 251 & 20.26 & 375 & 57 \\
\hline $10 / 29 / 01$ & 1.37 & 249 & 21.12 & 382 & 56 \\
\hline $10 / 30 / 01$ & 1.33 & 250 & 21.53 & 380 & 56 \\
\hline $10 / 31 / 01$ & 1.31 & 249 & 22.40 & 376 & 56 \\
\hline $11 / 01 / 01$ & 1.29 & 250 & 23.47 & 378 & 55 \\
\hline $11 / 02 / 01$ & 1.26 & 250 & 24.36 & 384 & 55 \\
\hline $11 / 03 / 01$ & 1.26 & 249 & 25.26 & 389 & 55 \\
\hline $11 / 04 / 01$ & 1.25 & 249 & 24.48 & 397 & 55 \\
\hline $11 / 05 / 01$ & 1.50 & 253 & 22.51 & 391 & 57 \\
\hline MINIMUM & 1.16 & 245 & 20.26 & 360 & 50 \\
\hline MAXIMUM & 1.51 & 253 & 29.45 & 421 & 61 \\
\hline AVERAGE & 1.31 & 249 & 25.60 & 385 & 55 \\
\hline $\begin{array}{l}\text { BURSTS FILTERED } \\
\text { OUT }(\%)\end{array}$ & 0 & & 0 & 0 & \\
\hline
\end{tabular}

${ }^{1}$ Flow sample volume located $27 \mathrm{~cm}$ above top of litter.

${ }^{2}$ MicroCAT temperature and conductance measured $13 \mathrm{~cm}$ above top of litter. 
Table B - 4. Daily mean flow velocities, MicroCAT water temperatures and specific conductances, and water depths at station GS-203 during deployment period 11/08/01 $0900-01 / 23 / 021600$

$\left[\mathrm{cm} / \mathrm{s}\right.$, centimeter per second; ${ }^{\circ} \mathrm{CW}$ from $\mathrm{MN}$, degrees clockwise from magnetic north; ${ }^{\circ} \mathrm{C}$, degrees Celsius; $\mu \mathrm{S} / \mathrm{cm}$, microsiemens per centimeter]

\begin{tabular}{|c|c|c|c|c|c|}
\hline Date & $\begin{array}{l}\text { Flow velocity' } \\
\quad(\mathrm{cm} / \mathrm{s})\end{array}$ & $\begin{array}{l}\text { Flow direction }{ }^{1} \\
\left({ }^{\circ} \mathrm{CW} \text { from MN) }\right.\end{array}$ & $\begin{array}{l}\text { Temperature }{ }^{2} \\
\left({ }^{\circ} \mathrm{C}\right)\end{array}$ & $\begin{array}{c}\text { Specific } \\
\text { conductance } \\
(\mu \mathrm{S} / \mathrm{cm})\end{array}$ & $\begin{array}{l}\text { Water depth } \\
\quad \text { (cm) }\end{array}$ \\
\hline $11 / 09 / 01$ & 1.24 & 249 & 22.85 & 414 & 56 \\
\hline $11 / 10 / 01$ & 1.31 & 250 & 23.33 & 423 & 56 \\
\hline $11 / 11 / 01$ & 1.25 & 250 & 23.79 & 434 & 55 \\
\hline $11 / 12 / 01$ & 1.30 & 251 & 24.00 & 441 & 55 \\
\hline $11 / 13 / 01$ & 1.32 & 250 & 23.80 & 452 & 55 \\
\hline $11 / 14 / 01$ & 1.30 & 249 & 23.93 & 460 & 55 \\
\hline $11 / 15 / 01$ & 1.31 & 248 & 23.08 & 465 & 55 \\
\hline $11 / 16 / 01$ & 1.30 & 250 & 23.03 & 468 & 54 \\
\hline $11 / 17 / 01$ & 1.31 & 250 & 23.59 & 468 & 54 \\
\hline $11 / 18 / 01$ & 1.25 & 248 & 23.88 & 467 & 54 \\
\hline 11/19/01 & 1.25 & 248 & 24.20 & 460 & 54 \\
\hline $11 / 20 / 01$ & 1.23 & 249 & 24.62 & 456 & 54 \\
\hline $11 / 21 / 01$ & 1.33 & 247 & 24.61 & 452 & 54 \\
\hline $11 / 22 / 01$ & 1.27 & 247 & 24.51 & 453 & 54 \\
\hline $11 / 23 / 01$ & 1.22 & 247 & 24.27 & 457 & 53 \\
\hline $11 / 24 / 01$ & 1.16 & 247 & 24.38 & 463 & 53 \\
\hline $11 / 25 / 01$ & 1.06 & 248 & 24.51 & 467 & 53 \\
\hline $11 / 26 / 01$ & 1.18 & 247 & 24.60 & 470 & 53 \\
\hline $11 / 27 / 01$ & 1.20 & 246 & 24.08 & 471 & 53 \\
\hline $11 / 28 / 01$ & 1.17 & 246 & 23.55 & 470 & 52 \\
\hline $11 / 29 / 01$ & 1.15 & 246 & 23.40 & 467 & 52 \\
\hline $11 / 30 / 01$ & 1.19 & 247 & 23.61 & 464 & 52 \\
\hline $12 / 01 / 01$ & 1.22 & 246 & 23.58 & 463 & 52 \\
\hline $12 / 02 / 01$ & 1.20 & 244 & 23.88 & 462 & 52 \\
\hline $12 / 03 / 01$ & 1.22 & 246 & 24.27 & 461 & 52 \\
\hline $12 / 04 / 01$ & 1.24 & 246 & 24.25 & 461 & 52 \\
\hline $12 / 05 / 01$ & 1.27 & 248 & 23.93 & 460 & 51 \\
\hline $12 / 06 / 01$ & 1.27 & 249 & 23.74 & 454 & 52 \\
\hline $12 / 07 / 01$ & 1.17 & 247 & 24.26 & 448 & 53 \\
\hline $12 / 08 / 01$ & 1.09 & 247 & 25.24 & 446 & 53 \\
\hline $12 / 09 / 01$ & 1.31 & 249 & 25.02 & 439 & 53 \\
\hline $12 / 10 / 01$ & 1.49 & 252 & 24.69 & 426 & 55 \\
\hline $12 / 11 / 01$ & 1.37 & 252 & 24.97 & 426 & 54 \\
\hline $12 / 12 / 01$ & 1.35 & 252 & 25.04 & 430 & 54 \\
\hline $12 / 13 / 01$ & 1.29 & 251 & 25.01 & 431 & 53 \\
\hline $12 / 14 / 01$ & 1.22 & 250 & 25.38 & 434 & 52 \\
\hline $12 / 15 / 01$ & 1.13 & 251 & 25.22 & 432 & 51 \\
\hline $12 / 16 / 01$ & 1.17 & 251 & 24.65 & 433 & 50 \\
\hline $12 / 17 / 01$ & 1.17 & 253 & 24.46 & 436 & 50 \\
\hline $12 / 18 / 01$ & 1.26 & 253 & 24.62 & 438 & 49 \\
\hline $12 / 19 / 01$ & 1.19 & 253 & 24.61 & 435 & 48 \\
\hline
\end{tabular}


Table B - 4. Daily mean flow velocities, MicroCAT water temperatures and specific conductances, and water depths at station GS-203 during deployment period 11/08/01 0900-01/23/02 1600 — Continued

[cm/s, centimeter per second; ${ }^{\circ} \mathrm{CW}$ from $\mathrm{MN}$, degrees clockwise from magnetic north; ${ }^{\circ} \mathrm{C}$, degrees Celsius; $\mu \mathrm{S} / \mathrm{cm}$, microsiemens per centimeter]

\begin{tabular}{|c|c|c|c|c|c|}
\hline Date & $\begin{array}{l}\text { Flow velocity } \\
\text { (cm/s) }\end{array}$ & $\begin{array}{l}\text { Flow direction }{ }^{1} \\
\left({ }^{\circ} \mathrm{CW} \text { from } \mathrm{MN}\right)\end{array}$ & $\begin{array}{c}\text { Temperature }^{2} \\
\left({ }^{\circ} \mathrm{C}\right)\end{array}$ & $\begin{array}{c}\text { Specific } \\
\text { conductance }^{2} \\
(\mu \mathrm{S} / \mathrm{cm})\end{array}$ & $\begin{array}{l}\text { Water depth } \\
\text { (cm) }\end{array}$ \\
\hline $12 / 20 / 01$ & 1.29 & 254 & 23.37 & 435 & 47 \\
\hline $12 / 21 / 01$ & 1.37 & 255 & 20.93 & 432 & 46 \\
\hline $12 / 22 / 01$ & 1.31 & 255 & 20.25 & 434 & 45 \\
\hline $12 / 23 / 01$ & 1.31 & 256 & 20.50 & 433 & 44 \\
\hline $12 / 24 / 01$ & 1.28 & 257 & 21.56 & 435 & 43 \\
\hline $12 / 25 / 01$ & 1.31 & 257 & 22.29 & 436 & 42 \\
\hline $12 / 26 / 01$ & 1.28 & 256 & 20.37 & 435 & 42 \\
\hline $12 / 27 / 01$ & 1.30 & 258 & 17.44 & 438 & 41 \\
\hline $12 / 28 / 01$ & 1.32 & 259 & 18.30 & 440 & 43 \\
\hline $12 / 29 / 01$ & 1.29 & 258 & 19.80 & 442 & 44 \\
\hline $12 / 30 / 01$ & 1.30 & 258 & 20.94 & 442 & 44 \\
\hline $12 / 31 / 01$ & 1.22 & 259 & 20.26 & 437 & 44 \\
\hline 01/01/02 & 1.21 & 261 & 19.65 & 431 & 44 \\
\hline $01 / 02 / 02$ & 1.26 & 259 & 19.76 & 430 & 44 \\
\hline 01/03/02 & 1.23 & 259 & 19.89 & 431 & 44 \\
\hline 01/04/02 & 0.93 & 258 & 15.77 & 436 & 44 \\
\hline 01/05/02 & 0.98 & 258 & 14.13 & 439 & 44 \\
\hline 01/06/02 & 0.97 & 261 & 16.43 & 442 & 44 \\
\hline 01/07/02 & 0.93 & 255 & 18.13 & 449 & 44 \\
\hline 01/08/02 & 1.14 & 252 & 15.56 & 450 & 44 \\
\hline 01/09/02 & $*$ & $*$ & 14.45 & 459 & 44 \\
\hline 01/10/02 & $*$ & $*$ & 14.85 & 473 & 44 \\
\hline $01 / 11 / 02$ & $*$ & $*$ & 16.93 & 486 & 40 \\
\hline $01 / 12 / 02$ & $*$ & $*$ & 18.52 & 497 & 32 \\
\hline 01/13/02 & $*$ & $*$ & 19.67 & 508 & 31 \\
\hline $01 / 14 / 02$ & $*$ & $*$ & 20.77 & 517 & 31 \\
\hline $01 / 15 / 02$ & $*$ & $*$ & 22.11 & 520 & 30 \\
\hline $01 / 16 / 02$ & $*$ & $*$ & 21.72 & 526 & 30 \\
\hline $01 / 17 / 02$ & $*$ & $*$ & 22.32 & 528 & 29 \\
\hline $01 / 18 / 02$ & $*$ & $*$ & 23.08 & 531 & 29 \\
\hline $01 / 19 / 02$ & $*$ & $*$ & 23.56 & 534 & 28 \\
\hline $01 / 20 / 02$ & $*$ & $*$ & 23.63 & 537 & 28 \\
\hline $01 / 21 / 02$ & $*$ & $*$ & 24.18 & 540 & 27 \\
\hline $01 / 22 / 02$ & $*$ & $*$ & 24.40 & 541 & 27 \\
\hline \multicolumn{6}{|l|}{ * All bursts filtered out } \\
\hline MINIMUM & 0.93 & 244 & 14.13 & 414 & 27 \\
\hline MAXIMUM & 1.49 & 261 & 25.38 & 541 & 56 \\
\hline AVERAGE & 1.23 & 252 & 22.24 & 459 & 47 \\
\hline $\begin{array}{l}\text { BURSTS FILTERED } \\
\text { OUT }(\%)\end{array}$ & 22 & & 0 & 0 & \\
\hline
\end{tabular}

${ }^{1}$ Flow sample volume located $27 \mathrm{~cm}$ above top of litter.

${ }^{2}$ MicroCAT temperature and conductance measured $13 \mathrm{~cm}$ above top of litter. 
Table B -5. Daily mean flow velocities, MicroCAT water temperatures and specific conductances, and water depths at station GS-203 during deployment period 01/24/02 1505-02/12/02 1335

[cm/s, centimeter per second; ${ }^{\circ} \mathrm{CW}$ from MN, degrees clockwise from magnetic north; ${ }^{\circ} \mathrm{C}$, degrees Celsius; $\mu \mathrm{S} / \mathrm{cm}, \mathrm{microsiemens}$ per centimeter]

\begin{tabular}{|c|c|c|c|c|c|}
\hline Date & $\begin{array}{l}\text { Flow velocity }{ }^{1} \\
\text { (cm/s) }\end{array}$ & $\begin{array}{l}\text { Flow direction }{ }^{1} \\
\left({ }^{\circ} \mathrm{CW} \text { from MN) }\right.\end{array}$ & $\begin{array}{c}\text { Temperature }{ }^{2} \\
\left({ }^{\circ} \mathrm{C}\right)\end{array}$ & $\begin{array}{c}\text { Specific } \\
\text { conductance }^{2} \\
(\mu \mathrm{S} / \mathrm{cm})\end{array}$ & $\begin{array}{l}\text { Water depth } \\
\text { (cm) }\end{array}$ \\
\hline $01 / 25 / 02$ & 0.59 & 248 & 23.48 & 545 & 25 \\
\hline $01 / 26 / 02$ & 0.59 & 248 & 23.86 & 546 & 25 \\
\hline $01 / 27 / 02$ & 0.60 & 249 & 24.19 & 546 & 24 \\
\hline $01 / 28 / 02$ & 0.57 & 251 & 23.85 & 547 & 24 \\
\hline $01 / 29 / 02$ & 0.62 & 252 & 23.63 & 549 & 23 \\
\hline $01 / 30 / 02$ & 0.66 & 252 & 24.01 & 547 & 23 \\
\hline $01 / 31 / 02$ & 0.69 & 252 & 23.91 & 548 & 22 \\
\hline 02/01/02 & 0.66 & 251 & 23.82 & 548 & 22 \\
\hline $02 / 02 / 02$ & 0.68 & 250 & 24.25 & 550 & 22 \\
\hline 02/03/02 & 0.66 & 251 & 24.89 & 545 & 22 \\
\hline $02 / 04 / 02$ & 0.62 & 246 & 23.02 & 546 & 21 \\
\hline $02 / 05 / 02$ & 0.62 & 242 & 19.90 & 549 & 21 \\
\hline 02/06/02 & 0.62 & 242 & 20.29 & 554 & 20 \\
\hline 02/07/02 & 0.63 & 240 & 21.45 & 556 & 20 \\
\hline 02/08/02 & 0.64 & 244 & 21.55 & 557 & 19 \\
\hline 02/09/02 & 0.64 & 241 & 21.68 & 550 & 19 \\
\hline 02/10/02 & 0.66 & 244 & 22.60 & 502 & 22 \\
\hline $02 / 11 / 02$ & 0.66 & 246 & 22.55 & 499 & 22 \\
\hline MINIMUM & 0.57 & 240 & 19.90 & 493 & 19 \\
\hline MAXIMUM & 0.69 & 252 & 24.89 & 563 & 25 \\
\hline AVERAGE & 0.63 & 247 & 22.94 & 536 & 22 \\
\hline $\begin{array}{l}\text { BURSTS FILTERED } \\
\text { OUT }(\%)\end{array}$ & 9 & & 0 & 0 & \\
\hline
\end{tabular}

\footnotetext{
${ }^{1}$ Flow sample volume located $10 \mathrm{~cm}$ above top of litter.
}

${ }^{2}$ MicroCAT temperature and conductance measured $13 \mathrm{~cm}$ above top of litter. 


\section{Appendix C}

Daily mean flow velocities, water-temperatures, specific conductances, and water depths at station GS-33, Shark River Slough, Everglades National Park, Florida during the 2001-2002 wet season. 
Table C - 1. Daily mean flow velocities, MicroCAT water temperatures and specific conductances, and water depths at station GS-33 during deployment period 08/09/01 1600-08/15/01 1530

[cm/s, centimeter per second; ${ }^{\circ} \mathrm{CW}$ from $\mathrm{MN}$, degrees clockwise from magnetic north; ${ }^{\circ} \mathrm{C}$, degrees Celsius; $\mu \mathrm{S} / \mathrm{cm}$, microsiemens per centimeter]

\begin{tabular}{|c|c|c|c|c|c|}
\hline Date & $\begin{array}{l}\text { Flow velocity }{ }^{1} \\
\qquad(\mathrm{~cm} / \mathrm{s})\end{array}$ & $\begin{array}{l}\text { Flow direction }{ }^{1} \\
\left({ }^{\circ} \mathrm{CW} \text { from } \mathrm{MN}\right)\end{array}$ & $\begin{array}{l}\text { Temperature }^{2} \\
\quad\left({ }^{\circ} \mathrm{C}\right)\end{array}$ & $\begin{array}{c}\text { Specific } \\
\text { conductance }^{2} \\
(\mu \mathrm{S} / \mathrm{cm})\end{array}$ & $\begin{array}{l}\text { Water depth } \\
\text { (cm) }\end{array}$ \\
\hline 08/10/01 & * & $*$ & 30.11 & 392 & 31 \\
\hline $08 / 11 / 01$ & $*$ & $*$ & 30.08 & 399 & 30 \\
\hline 08/12/01 & $*$ & $*$ & 31.09 & 405 & 30 \\
\hline 08/13/01 & $*$ & $*$ & 31.47 & 410 & 30 \\
\hline $08 / 14 / 01$ & $*$ & $*$ & 32.54 & 409 & 31 \\
\hline \multicolumn{6}{|l|}{$\begin{array}{l}* \text { Probe velocity range set to }+-250 \text {, } \\
\text { all bursts filtered out }\end{array}$} \\
\hline MINIMUM & & & 30.08 & 392 & 30 \\
\hline MAXIMUM & & & 32.54 & 410 & 31 \\
\hline AVERAGE & & & 31.05 & 403 & 30 \\
\hline BURSTS FILTERED OUT (\%) & 100 & & 0 & 0 & \\
\hline
\end{tabular}

${ }^{1}$ Flow sample volume located $10 \mathrm{~cm}$ above top of litter.

${ }^{2}$ MicroCAT temperature and conductance measured $6 \mathrm{~cm}$ above top of litter. 
Table C -2. Daily mean flow velocities, MicroCAT water temperatures and specific conductances, and water depths at station GS-33 during deployment period 08/16/01 1000 - 10/10/01 1530

$\left[\mathrm{cm} / \mathrm{s}\right.$, centimeter per second; ${ }^{\circ} \mathrm{CW}$ from $\mathrm{MN}$, degrees clockwise from magnetic north; ${ }^{\circ} \mathrm{C}$, degrees Celsius; $\mu \mathrm{S} / \mathrm{cm}$, microsiemens per centimeter]

\begin{tabular}{|c|c|c|c|c|c|}
\hline Date & $\begin{array}{l}\text { Flow velocity } \\
\qquad(\mathrm{cm} / \mathrm{s})\end{array}$ & $\begin{array}{l}\text { Flow direction } \\
\left({ }^{\circ} \mathrm{CW} \text { from } \mathrm{MN}\right)\end{array}$ & $\begin{array}{c}\text { Temperature }^{2} \\
\left({ }^{\circ} \mathrm{C}\right)\end{array}$ & $\begin{array}{c}\text { Specific } \\
\text { conductance } \\
(\mu \mathrm{S} / \mathrm{cm})\end{array}$ & $\begin{array}{l}\text { Water depth } \\
\text { (cm) }\end{array}$ \\
\hline 08/17/01 & $*$ & $*$ & 32.09 & 459 & 31 \\
\hline 08/18/01 & $*$ & $*$ & 32.54 & 476 & 31 \\
\hline 08/19/01 & $*$ & * & 32.58 & 492 & 31 \\
\hline 08/20/01 & $*$ & $*$ & 31.55 & 505 & 31 \\
\hline $08 / 21 / 01$ & $*$ & $*$ & 29.71 & 505 & 31 \\
\hline $08 / 22 / 01$ & $*$ & $*$ & 29.06 & 506 & 32 \\
\hline 08/23/01 & $*$ & * & 30.12 & 505 & 33 \\
\hline $08 / 24 / 01$ & $*$ & $*$ & 31.78 & 505 & 33 \\
\hline 08/25/01 & $*$ & $*$ & 32.32 & 502 & 34 \\
\hline 08/26/01 & * & * & 32.34 & 508 & 33 \\
\hline 08/27/01 & $*$ & $*$ & 32.04 & 506 & 33 \\
\hline 08/28/01 & $*$ & $*$ & 31.61 & 509 & 33 \\
\hline 08/29/01 & $*$ & $*$ & 31.58 & 513 & 33 \\
\hline 08/30/01 & $*$ & $*$ & 32.22 & 516 & 33 \\
\hline 08/31/01 & * & * & 32.31 & 519 & 33 \\
\hline 09/01/01 & $*$ & $*$ & 31.32 & 522 & 33 \\
\hline 09/02/01 & $*$ & $*$ & 31.23 & 517 & 34 \\
\hline 09/03/01 & * & * & 30.13 & 521 & 34 \\
\hline 09/04/01 & $*$ & $*$ & 30.05 & 498 & 36 \\
\hline 09/05/01 & $*$ & $*$ & 30.47 & 504 & 35 \\
\hline 09/06/01 & $*$ & $*$ & 30.07 & 525 & 35 \\
\hline 09/07/01 & $*$ & $*$ & 28.68 & 523 & 37 \\
\hline 09/08/01 & $*$ & $*$ & 28.50 & 511 & 38 \\
\hline 09/09/01 & $*$ & $*$ & 28.22 & 513 & 38 \\
\hline 09/10/01 & $*$ & $*$ & 28.08 & 512 & 39 \\
\hline 09/11/01 & $*$ & $*$ & 28.67 & 490 & 41 \\
\hline 09/12/01 & $*$ & $*$ & 27.71 & 436 & 47 \\
\hline 09/13/01 & $*$ & $*$ & 27.55 & 435 & 46 \\
\hline 09/14/01 & * & * & 26.97 & 420 & 48 \\
\hline
\end{tabular}


Table C-2. Daily mean flow velocities, MicroCAT water temperatures and specific conductances, and water depths at station GS-33 during deployment period 08/16/01 1000 - 10/10/01 1530 — Continued

$\left[\mathrm{cm} / \mathrm{s}\right.$, centimeter per second; ${ }^{\circ} \mathrm{CW}$ from $\mathrm{MN}$, degrees clockwise from magnetic north; ${ }^{\circ} \mathrm{C}$, degrees Celsius; $\mu \mathrm{S} / \mathrm{cm}$, microsiemens per centimeter]

\begin{tabular}{|c|c|c|c|c|c|}
\hline Date & $\begin{array}{l}\text { Flow velocity } \\
\qquad(\mathrm{cm} / \mathrm{s})\end{array}$ & $\begin{array}{l}\text { Flow direction' } \\
\text { ( }{ }^{\circ} \mathrm{CW} \text { from MN) }\end{array}$ & $\begin{array}{l}\text { Temperature }{ }^{2} \\
\left.\qquad{ }^{\circ} \mathrm{C}\right)\end{array}$ & $\begin{array}{c}\text { Specific } \\
\text { conductance }^{2} \\
(\mu \mathrm{S} / \mathrm{cm})\end{array}$ & $\begin{array}{l}\text { Water depth } \\
\text { (cm) }\end{array}$ \\
\hline 09/15/01 & $*$ & $*$ & 27.65 & 408 & 49 \\
\hline 09/16/01 & $*$ & $*$ & 28.37 & 411 & 48 \\
\hline 09/17/01 & $*$ & $*$ & 29.30 & 416 & 47 \\
\hline 09/18/01 & $*$ & $*$ & 29.21 & 402 & 48 \\
\hline 09/19/01 & $*$ & $*$ & 28.93 & 410 & 48 \\
\hline 09/20/01 & $*$ & $*$ & 29.54 & 420 & 48 \\
\hline $09 / 21 / 01$ & $*$ & $*$ & 30.19 & 428 & 47 \\
\hline $09 / 22 / 01$ & $*$ & $*$ & 30.54 & 443 & 46 \\
\hline 09/23/01 & $*$ & $*$ & 30.17 & 452 & 45 \\
\hline $09 / 24 / 01$ & $*$ & $*$ & 30.30 & 458 & 45 \\
\hline 09/25/01 & $*$ & $*$ & 30.78 & 459 & 44 \\
\hline 09/26/01 & $*$ & $*$ & 29.99 & 451 & 45 \\
\hline 09/27/01 & $*$ & $*$ & 28.39 & 438 & 46 \\
\hline 09/28/01 & $*$ & $*$ & 26.74 & 430 & 48 \\
\hline 09/29/01 & $*$ & $*$ & 25.00 & 373 & 57 \\
\hline 09/30/01 & $*$ & $*$ & 25.28 & 353 & 59 \\
\hline 10/01/01 & $*$ & $*$ & 26.24 & 330 & 57 \\
\hline $10 / 02 / 01$ & $*$ & $*$ & 26.46 & 372 & 56 \\
\hline $10 / 03 / 01$ & $*$ & $*$ & 26.69 & 382 & 55 \\
\hline 10/04/01 & $*$ & $*$ & 27.40 & 388 & 54 \\
\hline $10 / 05 / 01$ & $*$ & $*$ & 27.86 & 397 & 53 \\
\hline $10 / 06 / 01$ & $*$ & $*$ & 29.18 & 408 & 53 \\
\hline 10/07/01 & $*$ & $*$ & 30.65 & 421 & 52 \\
\hline 10/08/01 & $*$ & $*$ & 30.11 & 429 & 51 \\
\hline $10 / 09 / 01$ & $*$ & $*$ & 28.05 & 427 & 52 \\
\hline \multicolumn{6}{|c|}{$\begin{array}{l}* \text { Probe velocity range set to }+-250 \text {, } \\
\text { all bursts filtered out }\end{array}$} \\
\hline MINIMUM & & & 25.00 & 330 & 31 \\
\hline MAXIMUM & & & 32.58 & 525 & 59 \\
\hline AVERAGE & & & 29.53 & 458 & 42 \\
\hline $\begin{array}{l}\text { BURSTS FILTERED } \\
\text { OUT }(\%)\end{array}$ & 100 & & 0 & 0 & \\
\hline
\end{tabular}

${ }^{1}$ Flow sample volume located $10 \mathrm{~cm}$ above top of litter.

${ }^{2}$ MicroCAT temperature and conductance measured $6 \mathrm{~cm}$ above top of litter. 
Table C - 3. Daily mean flow velocities, MicroCAT water temperatures and specific conductances, and water depths at station GS-33 during deployment period 10/11/01 0900 - 11/06/01 1000

$\left[\mathrm{cm} / \mathrm{s}\right.$, centimeter per second; ${ }^{\circ} \mathrm{CW}$ from $\mathrm{MN}$, degrees clockwise from magnetic north; ${ }^{\circ} \mathrm{C}$, degrees Celsius; $\mu \mathrm{S} / \mathrm{cm}$, microsiemens per centimeter]

\begin{tabular}{|c|c|c|c|c|c|}
\hline Date & $\begin{array}{l}\text { Flow velocity } \\
\text { (cm/s) }\end{array}$ & $\begin{array}{l}\text { Flow direction }{ }^{1} \\
\left({ }^{\circ} \mathrm{CW} \text { from } \mathrm{MN}\right)\end{array}$ & $\begin{array}{l}\text { Temperature }^{2} \\
\quad\left({ }^{\circ} \mathrm{C}\right)\end{array}$ & $\begin{array}{c}\text { Specific } \\
\text { conductance } \\
(\mu \mathrm{S} / \mathrm{cm})\end{array}$ & $\begin{array}{l}\text { Water depth } \\
\text { (cm) }\end{array}$ \\
\hline $10 / 12 / 01$ & 1.16 & 187 & 27.31 & 430 & 51 \\
\hline $10 / 13 / 01$ & 1.19 & 187 & 27.05 & 439 & 51 \\
\hline $10 / 14 / 01$ & 1.19 & 187 & 26.97 & 447 & 50 \\
\hline 10/15/01 & 1.15 & 185 & 27.81 & 451 & 50 \\
\hline $10 / 16 / 01$ & 1.13 & 186 & 28.64 & 457 & 50 \\
\hline $10 / 17 / 01$ & 1.11 & 185 & 28.04 & 461 & 50 \\
\hline $10 / 18 / 01$ & 1.12 & 188 & 26.15 & 465 & 50 \\
\hline $10 / 19 / 01$ & 1.17 & 190 & 26.09 & 464 & 51 \\
\hline $10 / 20 / 01$ & 1.14 & 189 & 26.23 & 461 & 52 \\
\hline $10 / 21 / 01$ & 1.13 & 184 & 25.81 & 447 & 55 \\
\hline $10 / 22 / 01$ & 1.13 & 182 & 26.18 & 418 & 60 \\
\hline $10 / 23 / 01$ & 1.09 & 184 & 27.51 & 412 & 60 \\
\hline $10 / 24 / 01$ & 1.01 & 182 & 28.67 & 425 & 59 \\
\hline $10 / 25 / 01$ & 1.04 & 183 & 29.30 & 426 & 59 \\
\hline $10 / 26 / 01$ & 1.04 & 183 & 28.66 & 431 & 59 \\
\hline $10 / 27 / 01$ & 0.99 & 182 & 24.16 & 438 & 58 \\
\hline $10 / 28 / 01$ & 1.01 & 184 & 20.82 & 444 & 57 \\
\hline $10 / 29 / 01$ & 1.00 & 183 & 21.26 & 454 & 56 \\
\hline $10 / 30 / 01$ & 1.00 & 184 & 21.70 & 462 & 56 \\
\hline $10 / 31 / 01$ & 1.03 & 183 & 22.58 & 467 & 55 \\
\hline $11 / 01 / 01$ & 1.01 & 181 & 23.57 & 467 & 55 \\
\hline $11 / 02 / 01$ & 1.04 & 183 & 24.51 & 472 & 55 \\
\hline $11 / 03 / 01$ & 1.03 & 182 & 25.35 & 475 & 54 \\
\hline $11 / 04 / 01$ & 1.08 & 181 & 24.45 & 475 & 54 \\
\hline $11 / 05 / 01$ & 0.97 & 180 & 22.54 & 459 & 56 \\
\hline MINIMUM & 0.97 & 180 & 20.82 & 412 & 50 \\
\hline MAXIMUM & 1.19 & 190 & 29.30 & 475 & 60 \\
\hline AVERAGE & 1.08 & 184 & 25.65 & 450 & 54 \\
\hline $\begin{array}{l}\text { BURSTS FILTERED } \\
\text { OUT }(\%)\end{array}$ & 2 & & 0 & 0 & \\
\hline
\end{tabular}

${ }^{1}$ Flow sample volume located $26 \mathrm{~cm}$ above top of litter.

${ }^{2}$ MicroCAT temperature and conductance measured $6 \mathrm{~cm}$ above top of litter. 
Table C - 4. Daily mean flow velocities, MicroCAT water temperatures and specific conductances, and water depths at station GS-33 during deployment period 11/08/01 $0900-01 / 23 / 021630$

[cm/s, centimeter per second; ${ }^{\circ} \mathrm{CW}$ from $\mathrm{MN}$, degrees clockwise from magnetic north; ${ }^{\circ} \mathrm{C}$, degrees Celsius; $\mu \mathrm{S} / \mathrm{cm}$, microsiemens per centimeter]

\begin{tabular}{|c|c|c|c|c|c|}
\hline Date & $\begin{array}{l}\text { Flow velocity } \\
\qquad(\mathrm{cm} / \mathrm{s})\end{array}$ & $\begin{array}{l}\text { Flow direction }{ }^{1} \\
\left({ }^{\circ} \mathrm{CW} \text { from } \mathrm{MN}\right)\end{array}$ & $\begin{array}{c}\text { Temperature }^{2} \\
\left({ }^{\circ} \mathrm{C}\right)\end{array}$ & $\begin{array}{c}\text { Specific } \\
\text { conductance }^{2} \\
(\mu \mathrm{S} / \mathrm{cm})\end{array}$ & $\begin{array}{l}\text { Water depth } \\
\text { (cm) }\end{array}$ \\
\hline $11 / 09 / 01$ & 1.02 & 181 & 22.73 & 469 & 56 \\
\hline $11 / 10 / 01$ & $*$ & $*$ & 23.12 & 477 & 55 \\
\hline $11 / 11 / 01$ & $*$ & $*$ & 23.32 & 492 & 55 \\
\hline $11 / 12 / 01$ & $*$ & $*$ & 23.60 & 503 & 55 \\
\hline $11 / 13 / 01$ & $*$ & $*$ & 23.64 & 511 & 54 \\
\hline $11 / 14 / 01$ & $*$ & $*$ & 23.81 & 517 & 54 \\
\hline $11 / 15 / 01$ & $*$ & $*$ & 22.88 & 522 & 54 \\
\hline $11 / 16 / 01$ & $*$ & $*$ & 22.97 & 525 & 54 \\
\hline $11 / 17 / 01$ & $*$ & $*$ & 23.49 & 527 & 54 \\
\hline $11 / 18 / 01$ & $*$ & $*$ & 23.79 & 525 & 53 \\
\hline $11 / 19 / 01$ & $*$ & $*$ & 23.98 & 514 & 53 \\
\hline $11 / 20 / 01$ & $*$ & $*$ & 24.29 & 505 & 53 \\
\hline $11 / 21 / 01$ & $*$ & $*$ & 24.34 & 505 & 53 \\
\hline $11 / 22 / 01$ & $*$ & $*$ & 24.09 & 513 & 53 \\
\hline $11 / 23 / 01$ & $*$ & $*$ & 23.84 & 521 & 53 \\
\hline $11 / 24 / 01$ & $*$ & $*$ & 24.11 & 529 & 52 \\
\hline $11 / 25 / 01$ & $*$ & $*$ & 24.25 & 538 & 52 \\
\hline $11 / 26 / 01$ & $*$ & $*$ & 24.26 & 544 & 52 \\
\hline $11 / 27 / 01$ & $*$ & $*$ & 23.63 & 550 & 52 \\
\hline $11 / 28 / 01$ & $*$ & $*$ & 23.27 & 555 & 52 \\
\hline $11 / 29 / 01$ & $*$ & $*$ & 23.40 & 561 & 51 \\
\hline $11 / 30 / 01$ & 0.48 & 192 & 23.47 & 568 & 51 \\
\hline $12 / 01 / 01$ & 0.58 & 204 & 23.29 & 573 & 51 \\
\hline $12 / 02 / 01$ & 0.58 & 205 & 23.75 & 577 & 51 \\
\hline $12 / 03 / 01$ & 0.46 & 200 & 24.03 & 580 & 51 \\
\hline $12 / 04 / 01$ & 0.59 & 191 & 24.03 & 585 & 51 \\
\hline $12 / 05 / 01$ & 0.55 & 190 & 23.69 & 587 & 51 \\
\hline
\end{tabular}


Table C - 4. Daily mean flow velocities, MicroCAT water temperatures and specific conductances, and water depths at station GS-33 during deployment period 11/08/01 0900 - 01/23/02 1630 — Continued

[cm/s, centimeter per second; ${ }^{\circ} \mathrm{CW}$ from MN, degrees clockwise from magnetic north; ${ }^{\circ} \mathrm{C}$, degrees Celsius; $\mu \mathrm{S} / \mathrm{cm}$, microsiemens per centimeter]

\begin{tabular}{|c|c|c|c|c|c|}
\hline Date & $\begin{array}{l}\text { Flow velocity' } \\
\qquad(\mathrm{cm} / \mathrm{s})\end{array}$ & $\begin{array}{l}\text { Flow direction1 } \\
\left({ }^{\circ} \mathrm{CW} \text { from MN) }\right.\end{array}$ & $\begin{array}{l}\text { Temperature } \\
\left({ }^{\circ} \mathrm{C}\right)\end{array}$ & $\begin{array}{c}\text { Specific } \\
\text { conductance } \\
(\mu \mathrm{S} / \mathrm{cm})\end{array}$ & $\begin{array}{l}\text { Water depth } \\
\quad \text { (cm) }\end{array}$ \\
\hline $12 / 06 / 01$ & 0.63 & 185 & 23.55 & 580 & 51 \\
\hline $12 / 07 / 01$ & 0.85 & 182 & 24.22 & 572 & 52 \\
\hline $12 / 08 / 01$ & 0.85 & 183 & 24.95 & 576 & 52 \\
\hline $12 / 09 / 01$ & 0.90 & 184 & 24.53 & 570 & 53 \\
\hline $12 / 10 / 01$ & 0.85 & 184 & 24.49 & 544 & 55 \\
\hline $12 / 11 / 01$ & 0.82 & 181 & 24.68 & 531 & 54 \\
\hline $12 / 12 / 01$ & 0.83 & 184 & 24.69 & 536 & 53 \\
\hline $12 / 13 / 01$ & 0.80 & 183 & 24.77 & 544 & 52 \\
\hline $12 / 14 / 01$ & 0.84 & 185 & 25.07 & 549 & 52 \\
\hline $12 / 15 / 01$ & 0.82 & 186 & 24.81 & 558 & 51 \\
\hline $12 / 16 / 01$ & 0.81 & 185 & 24.39 & 560 & 50 \\
\hline $12 / 17 / 01$ & 0.86 & 186 & 24.19 & 564 & 49 \\
\hline $12 / 18 / 01$ & 0.84 & 188 & 24.37 & 568 & 49 \\
\hline $12 / 19 / 01$ & 0.81 & 188 & 24.34 & 574 & 48 \\
\hline $12 / 20 / 01$ & 0.79 & 187 & 22.88 & 581 & 47 \\
\hline $12 / 21 / 01$ & 0.79 & 191 & 20.51 & 582 & 46 \\
\hline $12 / 22 / 01$ & 0.79 & 193 & 19.82 & 581 & 45 \\
\hline $12 / 23 / 01$ & 0.82 & 195 & 20.05 & 578 & 45 \\
\hline $12 / 24 / 01$ & 0.76 & 195 & 21.37 & 577 & 44 \\
\hline $12 / 25 / 01$ & 0.66 & 192 & 22.00 & 579 & 43 \\
\hline $12 / 27 / 01$ & 0.64 & 192 & 17.43 & 579 & 42 \\
\hline $12 / 28 / 01$ & 0.63 & 193 & 18.19 & 577 & 42 \\
\hline $12 / 29 / 01$ & 0.60 & 195 & 19.32 & 574 & 41 \\
\hline $12 / 30 / 01$ & 0.62 & 194 & 20.18 & 572 & 40 \\
\hline $12 / 31 / 01$ & 0.61 & 201 & 19.79 & 565 & 40 \\
\hline 01/01/02 & 0.59 & 199 & 19.61 & 554 & 41 \\
\hline $01 / 02 / 02$ & 0.59 & 204 & 19.51 & 556 & 40 \\
\hline
\end{tabular}


Table C - 4. Daily mean flow velocities, MicroCAT water temperatures and specific conductances, and water depths at station GS-33 during deployment period 11/08/01 0900 - 01/23/02 1630 — Continued

[cm/s, centimeter per second; ${ }^{\circ} \mathrm{CW}$ from $\mathrm{MN}$, degrees clockwise from magnetic north; ${ }^{\circ} \mathrm{C}$, degrees Celsius; $\mu \mathrm{S} / \mathrm{cm}$, microsiemens per centimeter]

\begin{tabular}{|c|c|c|c|c|c|}
\hline Date & $\begin{array}{l}\text { Flow velocity1 } \\
\text { (cm/s) }\end{array}$ & $\begin{array}{l}\text { Flow direction' } \\
\text { ( }{ }^{\circ} \mathrm{CW} \text { from MN) }\end{array}$ & $\begin{array}{c}\text { Temperature }{ }^{2} \\
\left({ }^{\circ} \mathrm{C}\right)\end{array}$ & $\begin{array}{c}\text { Specific } \\
\text { conductance }^{2} \\
(\mu \mathrm{S} / \mathrm{cm})\end{array}$ & $\begin{array}{l}\text { Water depth } \\
\text { (cm) }\end{array}$ \\
\hline $01 / 03 / 02$ & 0.54 & 206 & 19.82 & 546 & 41 \\
\hline $01 / 04 / 02$ & 0.57 & 202 & 15.66 & 552 & 40 \\
\hline $01 / 05 / 02$ & 0.55 & 203 & 14.22 & 558 & 39 \\
\hline 01/06/02 & 0.54 & 202 & 16.46 & 558 & 39 \\
\hline 01/07/02 & 0.49 & 206 & 17.90 & 543 & 38 \\
\hline 01/08/02 & 0.38 & 198 & 15.39 & 529 & 37 \\
\hline 01/09/02 & 0.26 & 193 & 14.13 & 524 & 36 \\
\hline 01/10/02 & 0.29 & 183 & 14.34 & 522 & 36 \\
\hline $01 / 11 / 02$ & 0.32 & 197 & 16.11 & 517 & 35 \\
\hline $01 / 12 / 02$ & 0.27 & 193 & 17.51 & 516 & 35 \\
\hline $01 / 13 / 02$ & 0.28 & 193 & 18.62 & 518 & 34 \\
\hline $01 / 14 / 02$ & $*$ & $*$ & 20.10 & 519 & 34 \\
\hline $01 / 15 / 02$ & $*$ & $*$ & 21.58 & 521 & 33 \\
\hline $01 / 16 / 02$ & $*$ & $*$ & 21.43 & 521 & 33 \\
\hline 01/17/02 & $*$ & $*$ & 21.90 & 522 & 32 \\
\hline 01/18/02 & $*$ & $*$ & 22.41 & 524 & 32 \\
\hline $01 / 19 / 02$ & $*$ & $*$ & 22.79 & 528 & 32 \\
\hline 01/20/02 & $*$ & $*$ & 22.76 & 531 & 31 \\
\hline $01 / 21 / 02$ & $*$ & $*$ & 23.30 & 532 & 31 \\
\hline $01 / 22 / 02$ & $*$ & $*$ & 23.53 & 531 & 30 \\
\hline \multicolumn{6}{|l|}{ * All bursts filtered out } \\
\hline MINIMUM & 0.26 & 181 & 14.13 & 469 & 30 \\
\hline MAXIMUM & 1.02 & 206 & 25.07 & 587 & 56 \\
\hline AVERAGE & 0.65 & 192 & 21.90 & 545 & 46 \\
\hline $\begin{array}{l}\text { BURSTS FILTERED } \\
\text { OUT }(\%)\end{array}$ & 40 & & 0 & 0 & \\
\hline
\end{tabular}

${ }^{1}$ Flow sample volume located $26 \mathrm{~cm}$ above top of litter.

${ }^{2}$ MicroCAT temperature and conductance measured $6 \mathrm{~cm}$ above top of litter. 
Table C - 5. Daily mean flow velocities, MicroCAT water temperatures and specific conductances, and water depths at station GS-33 during deployment period 01/25/02 0915 - 02/12/02 1445

$\left[\mathrm{cm} / \mathrm{s}\right.$, centimeter per second; ${ }^{\circ} \mathrm{CW}$ from $\mathrm{MN}$, degrees clockwise from magnetic north; ${ }^{\circ} \mathrm{C}$, degrees Celsius; $\mu \mathrm{S} / \mathrm{cm}$, microsiemens per centimeter]

\begin{tabular}{|c|c|c|c|c|c|}
\hline Date & $\begin{array}{l}\text { Flow velocity' } \\
\qquad(\mathrm{cm} / \mathrm{s})\end{array}$ & $\begin{array}{l}\text { Flow direction }{ }^{1} \\
\left({ }^{\circ} \mathrm{CW} \text { from } \mathrm{MN}\right)\end{array}$ & $\begin{array}{l}\text { Temperature }{ }^{2} \\
\left({ }^{\circ} \mathrm{C}\right)\end{array}$ & $\begin{array}{c}\text { Specific } \\
\text { conductance } \\
(\mu \mathrm{S} / \mathrm{cm})\end{array}$ & $\begin{array}{l}\text { Water depth } \\
\quad(\mathbf{c m})\end{array}$ \\
\hline $01 / 26 / 02$ & 0.39 & 207 & 23.00 & 524 & 28 \\
\hline $01 / 27 / 02$ & 0.40 & 210 & 23.20 & 523 & 28 \\
\hline $01 / 28 / 02$ & 0.41 & 210 & 23.27 & 522 & 28 \\
\hline $01 / 29 / 02$ & 0.43 & 212 & 23.23 & 522 & 27 \\
\hline $01 / 30 / 02$ & 0.46 & 212 & 23.54 & 524 & 27 \\
\hline $01 / 31 / 02$ & 0.45 & 209 & 23.40 & 527 & 27 \\
\hline $02 / 01 / 02$ & 0.44 & 210 & 23.31 & 530 & 26 \\
\hline $02 / 02 / 02$ & 0.41 & 214 & 23.53 & 533 & 26 \\
\hline $02 / 03 / 02$ & 0.39 & 213 & 24.30 & 535 & 26 \\
\hline $02 / 04 / 02$ & 0.34 & 213 & 22.59 & 537 & 26 \\
\hline $02 / 05 / 02$ & 0.35 & 214 & 19.38 & 542 & 25 \\
\hline $02 / 06 / 02$ & 0.37 & 216 & 19.86 & 547 & 25 \\
\hline $02 / 07 / 02$ & 0.37 & 222 & 20.97 & 551 & 25 \\
\hline $02 / 08 / 02$ & 0.30 & 210 & 21.33 & 551 & 24 \\
\hline $02 / 09 / 02$ & 0.29 & 206 & 21.38 & 544 & 24 \\
\hline $02 / 10 / 02$ & 0.39 & 212 & 22.56 & 506 & 26 \\
\hline $02 / 11 / 02$ & 0.37 & 216 & 22.53 & 520 & 26 \\
\hline MINIMUM & 0.29 & 206 & 19.38 & 506 & 24 \\
\hline MAXIMUM & 0.46 & 222 & 24.30 & 551 & 28 \\
\hline AVERAGE & 0.39 & 212 & 22.43 & 532 & 26 \\
\hline $\begin{array}{l}\text { BURSTS FILTERED } \\
\text { OUT }(\%)\end{array}$ & 0 & & 0 & 0 & \\
\hline
\end{tabular}

${ }^{1}$ Flow sample volume located $13 \mathrm{~cm}$ above top of litter.

${ }^{2}$ MicroCAT temperature and conductance measured $6 \mathrm{~cm}$ above top of litter. 


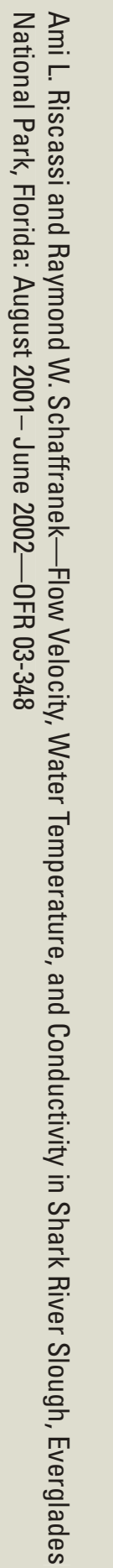

